\title{
Fotografia e a cultura política nos tempos da política da Boa Vizinhança
}

\begin{abstract}
Ana Maria Mauad ${ }^{1}$
RESUMO: $\bigcirc$ artigo analisa a produção fotográfica de Genevieve Naylor, fotógrafa contratada pelo Departamento de Estado dos Estados Unidos para produzir a imagem do Brasil como um bom vizinho, durante a Segunda Guerra Mundial. Na abordagem busca-se traçar paralelos entre a presença cultural da população negra nos Estados Unidos e no Brasil, por meio da análise do conteúdo e da expressão das imagens fotográficas produzidas por Naylor no Rio de Janeiro; dos contatos que ela estabeleceu com a intelectualidade brasileira e, finalmente, das letras de duas musicas cantadas por Carmen Miranda, um dos ícones da cultura popular de massa que configurava no Brasil dos anos 1940, a relação entre o nacional e o popular. PALAVRAS-CHAVE: Cultura negra. Fotografia. Política da Boa Vizinhança. Genevieve Naylor.

ABSTRACT: The article analyses Genevieve Naylor's photographic production, photographer commissioned by the US State Department to shape the Brazil's image as a good neighbor during World War II. The approach aims to build parallels between the cultural presence of the black population in US and Brazil, throughout the analysis of the content and expression of Naylor's photos in Rio; the contacts she made with Brazilian intellectuality during her stay at the city and, finally, the two lyrics of songs sang by Carmen Miranda, one of the icons of the mass popular culture, that prefigured in Brazil during the forties, the relationship of the popular and the national.

KEYWORDS: Black culture. Photograph. Good Neighbor policy. Genevieve Naylor.
\end{abstract}

A Boa Vizinhança foi uma política internacional encetada pelo governo de Franklyn Delano Roosevelt, desde 1940, para os países do continente americano, por uns dos órgãos do Departamento de Estado dos EUA, o Office of the Coordinator of Inter-American Affairs (OCIAA), dirigido pelo milionário Nelson Rockefeller. Esse órgão foi criado pelo governo de F.D. Roosevelt visando a garantir
1. Professora Associada do Departamento de História, Coordenadora do Laboratório de História oral e Imagem (LABHOI-UFF), Bolsista de Produtividade em Pesquisa do CNPq e Cientista do Nosso Estado FAPERJ (2013-2016) E-mail: <anammauad@uol.com.br>. 
2. Ver Renato Ortiz (1985, 1989).

3. Ver Ana Maria Mauad (2010, 2002).

4. Ver Erica Gomes Daniel Monteiro (2014) e Ana Maria Mauad (2009).

5. Ver Ana Maria Mauad (2005)

6. Ver Victor Burgin (1982, p.144). a solidariedade latino-americana para a causa liberal diante da expansão do nazifascismo, ao mesmo tempo em que criava uma área de reserva de mercado para os produtos norte-americanos durante a Segunda Guerra Mundial.

O OCIAA possuía escritórios nos países estratégicos da América do Sul, dentre eles, Argentina, Chile e Brasil. $\bigcirc$ Brasil representava uma peça-chave nas relações interamericanas, devido à necessidade dos Estados Unidos construírem uma base militar na região Nordeste do país, fato que possibilitou ao governo brasileiro negociar a construção da Companhia Siderúrgica Nacional, ponto de partida para a organização da indústria de base no Brasil. $\bigcirc$ alinhamento do Brasil com os EUA possibilitou a projeção internacional da cultura brasileira propalada pelo estado, que identificava o nacional ao popular, valorizando o samba, as belezas naturais e a diversidade étnica do Brasil2.

Nesse período, ainda, se configurou uma nova relação entre poder e cultura, bem como a elaboração de uma cultura política alicerçada em valores associados aos processos de internacionalização da cultura ocidental. Em pesquisas anteriores foram mapeadas expressões desse processo na produção cinematográfica, notadamente, nos filmes estrelados pela atriz e cantora Carmem Miranda entre 1941 e 19433; nas imagens publicitárias veiculadas nas revistas ilustradas durante a Segunda Guerra Mundial sob a orientação do Advertising Project ${ }^{4}$ e na imagem fotográfica, com destaque para a atuação da fotógrafa estadunidense, Genevieve Naylor, nos dois anos que atuou no Brasil (1940$1942)^{5}$. O que articula os filmes, a publicidade e a fotografia na abordagem das mudanças na cultura política brasileira dos anos 1940 é tanto a centralidade da imagem visual na configuração dos valores políticos e dos padrões comportamentais, quanto sua capacidade em fomentar a constituição de um espaço público visual. A análise proposta neste artigo retoma as imagens produzidas por Genevieve Naylor para se refletir como a fotógrafa percebeu as relações étnico-raciais no EUA e no Brasil por meio de suas lentes.

Neste estudo, opera-se com a noção de intertextualidade, segundo a qual as formas narrativas ou discursivas elaboradas na dinâmica social se apoiam e condicionam uma as outras. Dessa forma, a produção de imagens fotográficas, em um determinado 6 tempo e espaço, se sustenta em imagens já produzidas e essas orientam a educação do olhar dos fotógrafos em fase de aprendizado, mas também conformam formas e meios de ver e representar por meio de imagens técnicas o mundo visível. Por outro lado, o aprendizado de ver o que é significativo para cada situação cultural, envolve o acesso a um conjunto de valores que é apreendido nos contatos culturais entre sujeitos da experiência histórica.

A forma de compor suas fotografias revela o diálogo que a fotógrafa estabeleceu com as referências visuais de seu tempo, principalmente aquelas associadas à produção artística dos anos 1930, cuja valorização do indivíduo se fazia em consonância ao papel por ele desempenhado nas relações sociais. $\bigcirc$ resultado da conjugação dessas referências foi a elaboração de um discurso visual sobre alteridade plural dos brasileiros, jovens, crianças e velhos, possível de ser 
apreendida pela gente comum dos Estados Unidos, o público alvo das suas fotografias. Destaca-se, em suas imagens, a presença negra na sociedade brasileira e observa-se nas suas fotografias uma diferenciação entre as formas de deixar-se fotografar da população afro-brasileira e as escolhas técnicas e estéticas realizadas pela fotógrafa, principalmente no que diz respeito à negociação da pose. Compreende-se aí a produção de uma memória negociada entre o mundo branco, do qual provem a fotógrafa, e o afro-brasileiro.

O eixo conceitual que orienta esta reflexão opera com a noção da prática fotográfica como experiência social, política e, marcadamente, histórica. O roteiro proposto inicia-se pela apresentação da noção de fotografia pública, uma prática por meio da qual se configura uma cultura política visual. Na era da Boa Vizinhança uma cultura política dessa natureza desempenhou papel fundamental na elaboração da política externa dos Estados Unidos para as "demais repúblicas americanas" - denominação dada pelas agências do governo dos EUA para o conjunto de países que formavam a América do Norte, Central e do Sul, durante a Segunda Guerra Mundial - que contribuiu para a internacionalização da cultura brasileira definida como tal na Era Vargas. Nesse contexto, busca-se avaliar o trabalho da fotógrafa Genevieve Naylor no bojo de uma cultura política radical desenvolvida nos Estados Unidos dos anos 1930 e 1940, perpassada pelas tensões criadas entre os protocolos oficiais dos governos e a forma como artistas e intelectuais se engajaram na causa defendida pela política da Boa Vizinhança, a união das Américas contra o avanço do nazifascismo.

Portanto, o trabalho de Naylor é analisado segundo as condições históricas do processo de produção de sentido social da época em que atuava, destacando-se para o período a noção de fotografia pública e sua relação com as culturas políticas. Enfatiza-se na análise a forma como a população afroamericana surge na cena cultural dos Estados Unidos nos anos 1930-40. Paralelamente busca-se identificar como a população afro-brasileira dos anos 1940, ganharia uma expressão própria pelas lentes de Naylor. Expressão essa em que se evidenciaria a tensão entre a valorização de elementos da cultura nacional popular pela fotógrafa, percebidos nos contatos com intelectuais brasileiros e nos limites impostos pelos protocolos colocados pelas agências oficiais brasileiras para produzir a imagem do Brasil no exterior, dentre os quais, a valorização dos monumentos históricos, belezas naturais e a arquitetura moderna que emergia no cenário da Capital Federal.

As imagens de Naylor sobre o carnaval do Rio dos anos 1940 foram escolhidas como a série em que a população afro-brasileira é evidenciada visualmente por meio do movimento do corpo e da ocupação os espaços públicos da Capital. A esse conjunto foram associado dois sambas de finais dos anos 1930 cantados por Carmem Miranda para produzir um texło videográfico, em que se propõe uma representação atualizada pelo olhar do presente da cultura afrobrasileira nos anos 1940. 
7. Operamos o conceito de geração como uma escala temporal, variável, definida a partir do conjunto de experiências sociais que constroem o universo da cultura política de uma época. Sobre esse conceito ver: Jean-François Sirinelli (1996).

8. Ver Siegfried Kracauer (1980).

9. Ver Ana Maria Mauad (2008).
Cultura política e a experiência fotográfica - a politização do olhar

A experiência fotográfica no século XX definiu um novo regime visual, que democratizou o retrato e pluralizou as formas de representação do sujeito na esfera pública e privada. Dos recônditos da intimidade às praças públicas, a fotografia enquadrou memórias, registrou acontecimentos, capturou imagens de significativa beleza, flagrou personalidades, encampou lutas sociais, dimensionando a história contemporânea em seus múltiplos sentidos. Não se busca mais apenas a história por detrás das imagens, mas a história das imagens e dos sujeitos que, atentos às transformações do mundo, produziram essas mesmas imagens. A forma como essas imagens foram elaboradas e o envolvimento dessa prática fotográfica com os acontecimentos e vivências que registrava definem um lugar social para $\circ$ fotógrafo ou fotógrafa que as produziu e, ao mesmo tempo, aponta para o pertencimento desses com seu grupo ou sua geração?

A fotografia pública, ao longo do século passado, pode ser compreendida segundo dois rumos: o da prática criativa e da expressão crítica do mundo visível $^{8}$. No primeiro caminho, o da prática criativa, a fotografia, entre várias tendências, foi pensada, por um lado, como expressão autoral ligada ao pictorialismo e aos padrões clássicos de representação artística e, por outro lado, associada às vanguardas artísticas, o que colocov em questão o próprio princípio realista. No segundo caminho, esteve associada à imprensa ilustrada e à produção de notícias, agindo como janelas que se abriam para o mundo, figurando-o da forma mais realista. Ainda nesse segundo rumo ou tendência, a produção fotográfica novecentista associou-se às práticas de registro social, servindo para documentar as condições de vida de diferentes setores sociais, os deslocamentos humanos, conflitos e situações-limite.

Nesse segundo caso, o agenciamento das imagens foi feito de forma independente, como nos exemplos das agências fotográficas Dephot e Magnum, ou associada a projetos governamentais, como no caso da Farm Security Administration, agência governamental criada nos anos 1930 para, entre outras funções, documentar a recuperação dos Estados Unidos, durante a recessão. Entretanto, tanto em um como em outro tipo de agenciamento, a autoria fotográfica se define pelo engajamento em uma causa ou projeto?

O trabalho de fotógrafos comissionados pelo governo dos EUA para produzir registro das condições de vida nas cidades, das obras públicas ou da ação social do Estado permitiu a avaliação de estratégias de visibilidade da ação governamental segundo os códigos que organizam a cultura visual das sociedades burguesas ocidentais desde fins do século XIX. Um dos elementos que fundamentam essa ação foi atribuir dimensão mágica à qual os primeiros usos da imagem técnica estavam associados, às representaç̃es do poder; um segundo elemento importante foi a incorporação de artistas ao projeto governamental, cujo trabalho vinha acompanhado de uma educação do olhar e de um aprendizado estético, que sintonizava com os valores da sociedade liberal, incentivadora das artes e talentos. 
Paralelamente, o circuito social da fotografia pública prescrevia que, para que ela existisse de fato, deveria ter garantida a sua publicação em revistas e jornais, ou ainda, em álbuns e exposições oficiais, como forma de ritualizar o processo de apropriação coletiva das representações visuais.

As imagens fotográficas da depressão americana são emblemáticas nesse sentido, pois configuraram substancialmente o imaginário da sociedade dos Estados Unidos nos anos 1930. Entretanto, se atentarmos para o circuito social, ou seja, as etapas de produção, circulação, consumo e agenciamento, é possível constatar que foram as formas de agenciamento político dessas imagens - em filmes, documentários, cartazes, produzidos por agentes sociais desconectados do Estado - que garantiram a produção de um imaginário social em paralelo ao trabalho de enquadramento da memória visual pelo Estado. Vale também ressaltar que a variedade de imagens produzidas no âmbito da Farm Security Administration (FSA) estava estreitamente associada ao grupo de fotógrafos contratados por Roy Stryker, os quais romperam os protocolos estritos estabelecidos pelo chefe e foram em busca de imagens da América profunda ${ }^{10}$.

A defesa dos valores humanistas nas fotografias públicas produzidas nos Estados Unidos dos anos 1930 foi feita por fotógrafos engajados na elaboração de uma cultura política que se construiu em torno da defesa da justiça social, pela integração racial, pelo antifascismo e pela cultura de vanguarda radical. As fotografias dessa geração de fotógrafos, os quais se identificavam como os "concerned photographers", tornaram-se emblemas de uma cultura política que entraria na clandestinidade no pós-guerra, com emergência da guerra fria ${ }^{11}$. Foi nesse ambiente que se formou Genevieve Naylor, a fotógrafa da política da Boa Vizinhança.

Proveniente de uma família rica do Estado de Nova York, Naylor formouse dentro dos padrões da cultura burguesa e liberal americana. Aos 15, anos vivendo em Pittsfield, no estado de Massachusetts, voltou-se para o estudo da pintura artística, motivo o qual a colocou em contato com seu futuro companheiro, Misha Reznikoff. Dez anos mais velho que ela, o artista russo que se radicara nos EUA na década de 1920, fugindo do contexto revolucionário da Rússia, lecionava na escola de artes onde Naylor passou a estudar ${ }^{12}$.

$\bigcirc$ encontro dos dois rendeu uma pareceria afetiva e intelectual que durou uma vida inteira. $\bigcirc$ casal, juntos desde meados dos anos 1930 e morando em Greenwich Village, o bairro boêmio da cidade de Nova York, entrou em contato com a cultura radical e vanguardista, que defendia os ideais igualitários de uma sociedade democrática antissegregacionista, ao mesmo tempo em que valorizava o jazz e a arte experimental europeia. Destaca-se nesse contexto a formação de Naylor na New York School of Social Research, centro de estudos que recebeu boa parte dos intelectuais da esquerda ocidental que fugiu da Europa com a ascensão do nazifascismo, e conseguiu congregar sob a chancela da pesquisa social trabalhos de artistas visuais, dentre os quais a renomada fotógrafa Berenice Abbot, que passaria a ser a mentora de Naylor e a principal responsável por sua "virada fotográfica" 13.
10. Sobre a trajetória da FSA e seu papel na politização no uso da imagem fotográfica, ver Pete Daniel et al. (1987), Forest Jack Hurley (1977) e James Curtis (1989).

11. Vale aqui uma nota de dissenso em relação a essa interpretação. Estudos sobre as imagens públicas realizados por teóricos da imagem fotográfica dentre os quais Martha Rosler (2007), coloca por terra essa grande narrativa da fotografia documental nos Estados Unidos, diferenciando a geração de Jacob Riis e Lewis Hine, fotógrafos reformistas e polemistas, da geração do New Deal, completamente agenciados pela ideologia do estado do bem estar social, ainda mais daqueles denominados de novos documentaristas, que ganham a cena cultural no final dos anos 1960, dentre os quais se destacam Lee Friedlander, Diane Arbus e Garry Winogrand.

12. Ver George Ermakoff (2013) e Ana Maria Mauad (2005).

13. Idem. 
14. É importante destacar que o WPA foi um dos grandes projetos do New Deal, plano de reconstrução dos Estados Unidos levado adiante por sucessivas administrações do presidente Frank Delano Roosevelt, e estava voltado para empregar milhares de trabalhadores na construção de pontes, prédios públicos, parques, rodovias, aeroportos, etc. Paralelamente, o WPA foi responsável por fomentar as artes, empregando artistas na produção de obras de arte pública, como também por meio do financiamento de projetos artísticos de apelo comunitário. O WPA, nas artes, foi a base para a criação das principais linhas atuais de apoio financeiro às artes e humanidades nos EUA, desenvolvidas pelo National Foundation for the Arts e pelo The National Endowment for the Humanities Cf. <http:// www.pbs.org/wgbh/ a mericanexperience/ features/general-article/ dustbowl-wpa>, acesso em 08/03/2014.
Em 1939, Genevieve Naylor, aos 24 anos, já era fotógrafa credenciada pela Associated Press e reconhecida nos meios fotográficos de Nova York pelo seu trabalho no Work Projects Administration (WPA), que funcionou de 1935 a 1943 e que até 1939 era denominado de Work Progress Administration ${ }^{14}$. Como veremos a seguir, foi sua experiência no Harlen, associada ao WPA, a base para sensibilizar seu olhar para a população afro-brasileira.

Com essas credenciais, Naylor foi contratada por Nelson Rockfeller, então diretor do Office of the Coordinator of Inter-American Affairs (OCIAA), juntamente com mais dois outros fotógrafos, Kidder Smith e Alan Fisher, para produzirem uma documentação visual sobre o Brasil. O primeiro ficou a cargo de registrar a moderna arquitetura brasileira e o segundo foi designado para a seção de higiene do Office, em que teve como missão registrar as condições de vida e trabalho na região Norte do país. A Naylor coube fotografar o cotidiano dos brasileiros e brasileiras, segundo um programa que visava estabelecer pontes culturais entre as duas nações.

O significado dessa iniciativa para o Departamento de Estado dos EUA estava associado à necessidade de apresentar o Brasil para o público norteamericano, visto como um país irmão que compartilhava os valores morais e políiticos das democracias liberais. Já a autorização do governo brasileiro associavase ao alinhamento do país às forças antifascistas e, consequentemente, à confirmação da pareceria junto ao governo dos Estados Unidos, como sócio privilegiado nas relações interamericanas durante a Segunda Guerra Mundial.

A população afro-brasileira pelas lentes da fotógrafa a Boa Vizinhança

O casal Genevieve Naylor e Peter Reznikoff chegou ao Brasil em outubro de 1940, ela como a fotógrafa oficial da Boa Vizinhança, ele como integrante de uma missão artística para criar o Museu de Arte Moderna no Rio. A missão de Naylor era a de fotografar um Brasil que fosse bom vizinho e amigável, para ser exibido nos Estados Unidos e a de Reznikoff era a de participar do fomento ao campo das artes no Brasil, nos moldes dos museus dos Estados Unidos.

Ambas as iniciativas estavam em consonância com a perspectiva políitica adotada pelo OCIAA, em que se investia no estreitamento dos laços culturais e na consolidação de um mercado de consumo para o pós-guerra na América do Sul. Do ponto de vista da cultura política, a postura do OCIAA exaltava os valores da cultura liberal, expressos tanto pela cultura erudita, como pela cultura popular de massa. No que tange à primeira vertente, investiu-se na valorização da música erudita de raiz local, nas artes plásticas, na criação do MAM-RJ e na arquitetura modernista, focalizada pelo já mencionado fotógrafo Kidder Smith, responsável pelas fotografias que integraram a exposição principal do MOMA em 1943, a notória Brazil Builds, totalmente voltada para a arquitetura modernista brasileira.

Paralelamente, investia-se, por meio de produtos da cultura de massa, na configuração de uma nova geografia imaginária para o continente americano. 
Nessa operação, destacam-se o fomento ao cinema, através dos filmes do "ciclo da Boa Vizinhança" e de seus ícones - Carmem Miranda e Zé Carioca - e da imagem dos produtos americanos para serem consumidos no Brasil, dentre os quais se destacava a Coca-Cola. Tanto no cinema como na publicidade, projetou-se a transformação do que era próprio ou "típico" na formação social de cada país, numa espécie de folclorização da geopolítica interamericana. Assim, criou-se a baiana estilizada, o malandro legal, o gringo simpático, o camponês alegre, enfim, para cada país um tipo que incorpora uma função política no mosaico americano ${ }^{15}$.

A fotografia de Naylor, entretanto, não reproduziu esse protocolo, pois se orientou pela busca do que o Brasil teria de semelhante e de diferente em relação aos EUA, do ponto de vista da cultura humanista na qual conformou seu olhar fotográfico. Nesse jogo de afinidades seletivas, a fotógrafa produziu uma imagem do Brasil que associava a cultura urbana internacionalizada a uma ambiência rural composta pela paisagem de pequenas cidades no interior do Brasil, seus habitantes e suas práticas culturais. Uma estratégia que foi bem recebida pela população dos EUA, como se evidenciou nas manchetes e críticas publicadas nos jornais sobre a exposição Faces and Places in Brazil organizada em 1943, no MOMA-NY, e que correu o país nos anos subsequentes. Nessas reportagens, destacavam-se aspectos comuns da vida urbana de ambos os países e se destacava a majestosa natureza do Brasil'b.

Durante a sua permanência no país, Naylor e Misha moraram no Rio de Janeiro, no bairro litorâneo do Leme, bem em frente ao mar, na avenida Atlântica. Nos dois anos em que estiveram no Brasil, viajaram pelo país, para visitarem as cidades históricas de Minas Gerais, registrando os festejos da Semana Santa, foram para São Paulo e desceram o rio São Francisco, documentando visualmente o cotidiano da população ribeirinha e a seca que assolou a região Nordeste em 1942. O resultado dessas viagens foi a formação de um conjunto de mais de mil e trezentas fotografias, que revelam um pais plural e perpassado por forte diferenças regionais, um registro fotográfico amplo e original sobre o Brasil dos anos $1940^{17}$.

As imagens fotográficas produzidas por Naylor na cidade do Rio de Janeiro compõem cerca de $40 \%$ do conjunto de imagens ampliadas de sua coleção ${ }^{18}$. Evidencia-se a atenção da fotógrafa em registrar o bairro internacionalmente conhecido, Copacabana (13\%), que ganhou uma seção exclusiva na exposição de 1943, bem como o centro da cidade (2 1\%), principal local de circulação da população, onde se estabeleciam os edifícios públicos e comerciais mais importantes. A fotógrafa também registrou os morros da cidade e bairros suburbanos $(7 \%)$, regiões fora do circuito turístico da cidade. Nessas imagens, revela-se o interesse de Naylor pelas práticas de cultura popular de procedência afro-brasileira, dentre as quais, as rodas de samba, o jongo e outros ritmos e danças que uniam performance corporal e musical no espaço comunitário. Vale destacar que tais práticas culturais já ganhavam fama e eram vistos com simpatia pela intelectualidade engajada na ideologia do nacional-popular. Isso
15. Ver Ana Maria Mauad (2002, 2009, 2010).

16. Ver Ana Maria Mauad (2005).

17. Um conjunto significativo de fotografias da fotógrafa foi publicado por George Ermakoff (2013).

18. Trabalhei com uma amostragem da sua coleção composta por 264 fotografias provenientes de duas fontes diferentes: 104 fotos publicadas no livro de Robert Levine (1997) e 160 fotos da Biblioteca do Congresso dos Estados Unidos, na seção Photos and Prints, arquivadas na rubrica Hispanic American Culture e identificadas como pertencentes ao US State Department. Vale ressaltar que a obra de Naylor compõe um acervo demais de 1300 fotografias relativas ao período de sua permanência no Brasil. Uma pequena parte do acervo, pouco mais de 200 fotografias, encontra-se na Biblioteca do Congresso, em Washington, DC. O conjunto mais completo e significativo desse material permanece sob a guarda de seu filho Peter Reznikoff, que publicou, juntamente com o falecido historiador norte-americano Robert Levine, parte do acervo no livro intitulado: Brazilian Photographs of Genevieve Naylor. 1940-1942; ver Robert Levine (1998). Embora só tenha trabalhado com as fotografias ampliadas, na pesquisa de fontes no arquivo pessoal de Peter Reznikoff tive acesso às folhas de contato do trabalho desenvolvido no Brasil. 
19. Agradeço Peter Reznikoff pela autorização de publicação dessas imagens de Genevieve Naylor. A reprodução limitase aos usos acadêmicos dessas imagens neste artigo, sendo vetada a sua reprodução para fins comerciais.

20. Trata-se do documento "Assuntos que devem ser fotografados no Rio de Janeiro", c. 1941, emitido pela Divisão de Turismo do DIP, a qual tive acesso por cortesia de Peter Reznikof,; ver, a esse respeito, Ana Maria Mauad (2005, p. 52). explica, em certa medida, o porquê de uma fotógrafa "gringa", mas com amigos cariocas, ter chegado tão longe do cartão postal.

Nessas imagens, Naylor adotou um enquadramento que ora valorizava a população no seu espaço social, pela opção de colocar as pessoas contra o fundo da paisagem $162 \%$ das imagens em dois planos com a figuração humana plano central) (Figuras 1 a 6), ora as definiam na sua singularidade, por meio da modalidade do retrato fotográfico (30\%) (Figuras 7 e 8), que não deixava de incluir objetos pessoais que a identificassem socialmente. As fotografias que seguem foram escolhidas para compor um conjunto de referências e configuram o padrão predominante na abordagem de Naylor, cuja estética valorizava a figuração humana na sua experiência cotidiana considerando-se elementos de distinção como cor, gênero, geração e classe ${ }^{19}$.

A abordagem visual adotada por Naylor para representar o Rio de Janeiro como capital federal afinava-se com referências estéticas do pluralismo cultural, próprias do ambiente intelectual e artístico de Nova York dos anos 1930, mas foram, sobretudo, incrementadas pelo contato com a intelectualidade carioca com a qual conviveu dentro do ambiente de valorização da cultura nacionalpopular. Entretanto, apresenta-se também tensionada pela pedagogia visual da política implementada pelo OCIAA, que buscava fundamentar em imagens o que era típico de cada país, ao mesmo tempo em que também buscava alternativas diante dos protocolos rígidos de representação definidos pelo governo brasileiro, que, de acordo com documento emitido pelo Departamento de Imprensa e Propaganda (DIP) que a autorizava trabalhar no Brasil, indicava que a sua função estava restrita fotografar os pontos turísticos da Capital Federal20.

Destacam-se duas mediações culturais importantes na produção das imagens de afro-brasileiros na fotografia de Genevieve Naylor: a primeira é tributária de sua experiência como fotógrafa documentarista nos EUA, sobretudo a experiência vivenciada no Harlem como parte do WPA, e a segunda associa-se à experiência de viver no Rio de Janeiro e conviver com pessoas de procedências variadas, num ambiente marcado pela censura do Estado Novo, mas repleto de referências festivas da cultura nacional-popular que elegeu o samba, o carnaval e o futebol como símbolos da nacionalidade.

Cultura afro-americana nos EUA dos anos 1918-1948 - Harlem Renaissance, Naylor e o Harlem Project

O Harlem, uma subdivisão da cidade de Nova York situada ao norte de Manhattan, foi, entre os anos 1914 e 1918, gradualmente habitada por uma população de migrantes do Sul rural, na sua grande maioria de afroamericanos. Desde essa época, o bairro tornou-se referência da cultura afroamericana, cujos artífices, dentre eles W.E.B Dubois, defendiam em suas obras, - orgulho racial e a dignidade da população negra nos EUA, da qual provinham. 


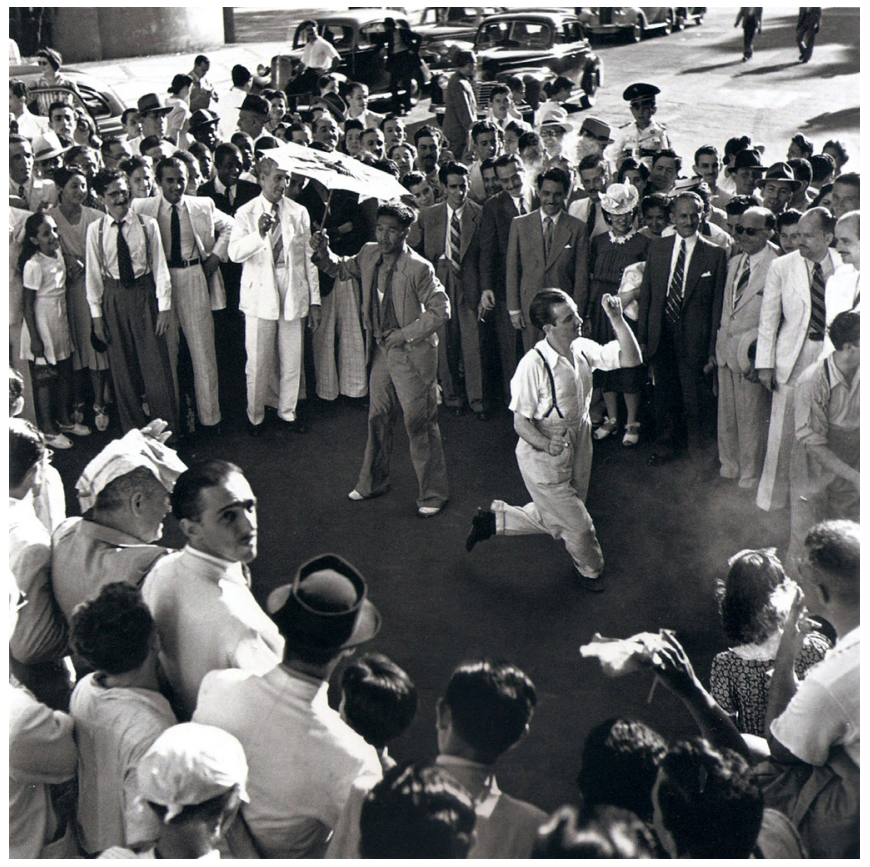

Figura 1 - Centro da Cidade, Rio de Janeiro, 1941, Genevieve Naylor, coleção Peter Reznikof@.

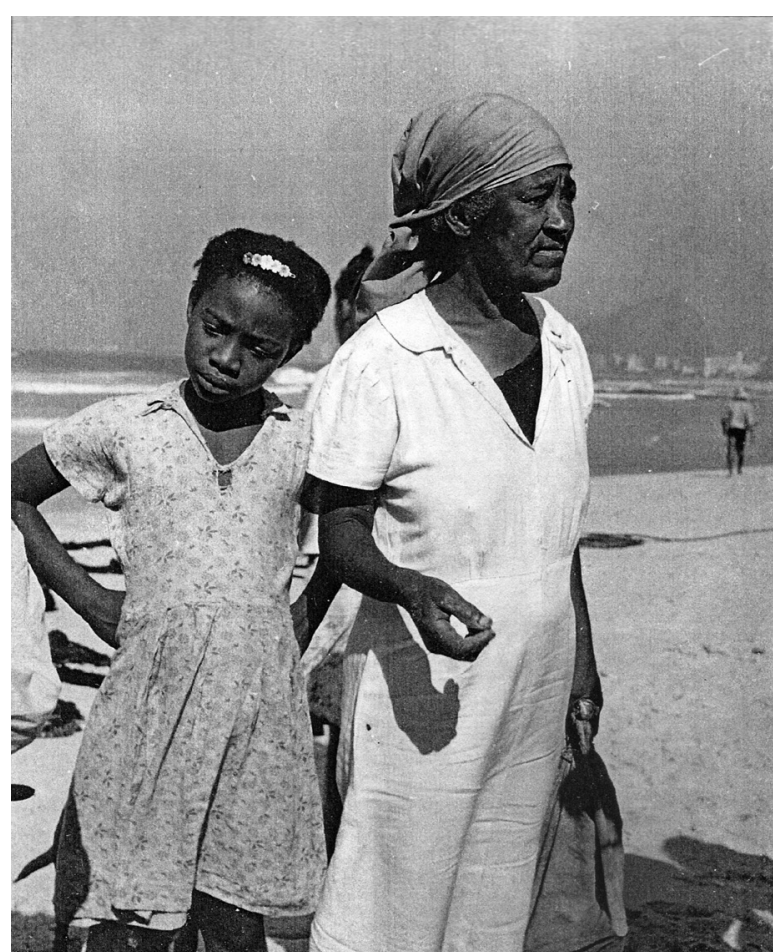

Figura - 3 Praia de Copacabana, Rio de Janeiro, 1941, Genevieve Naylor, coleção Peter Reznikof@.

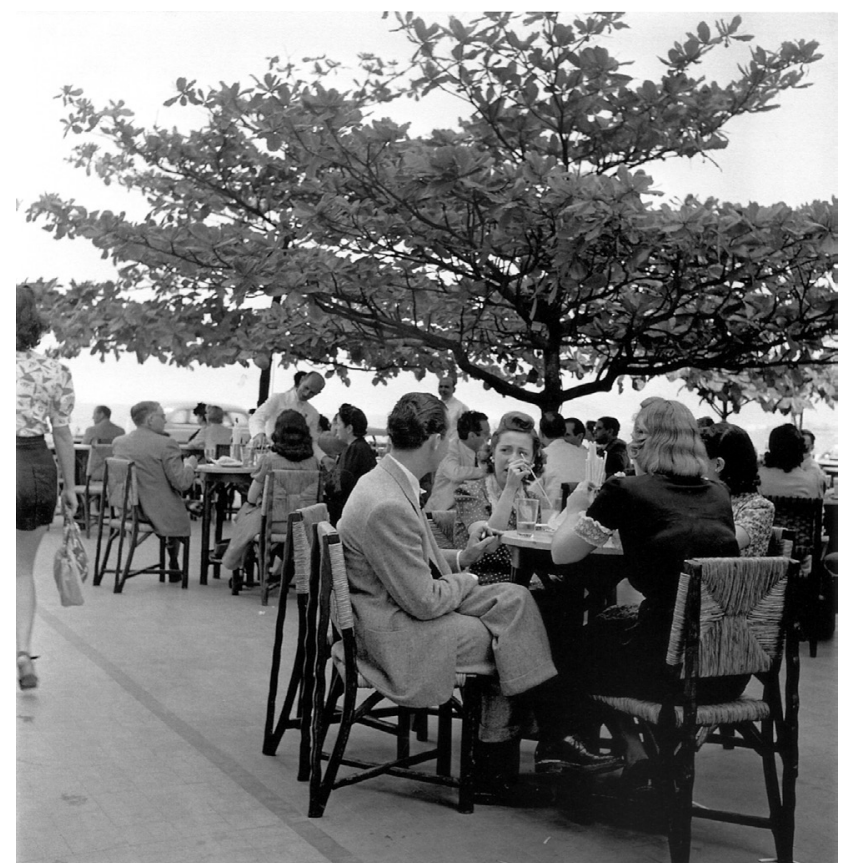

Figura 2 - Praia de Copacabana, Rio de Janeiro, 1941 , Genevieve Naylor, coleção Peter Reznikof@.

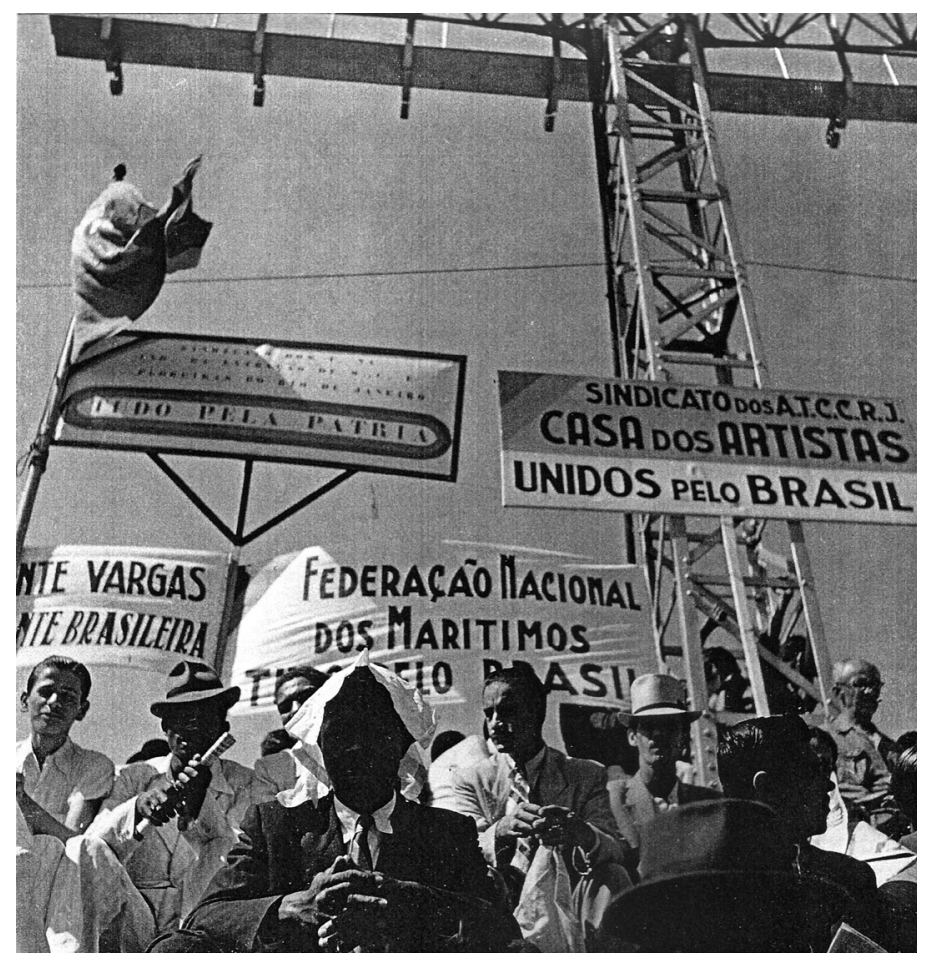

Figura 4 - Manifestação sindical. Rio de Janeiro, 1941, Genevieve Naylor, coleção Peter Reznikof@. 


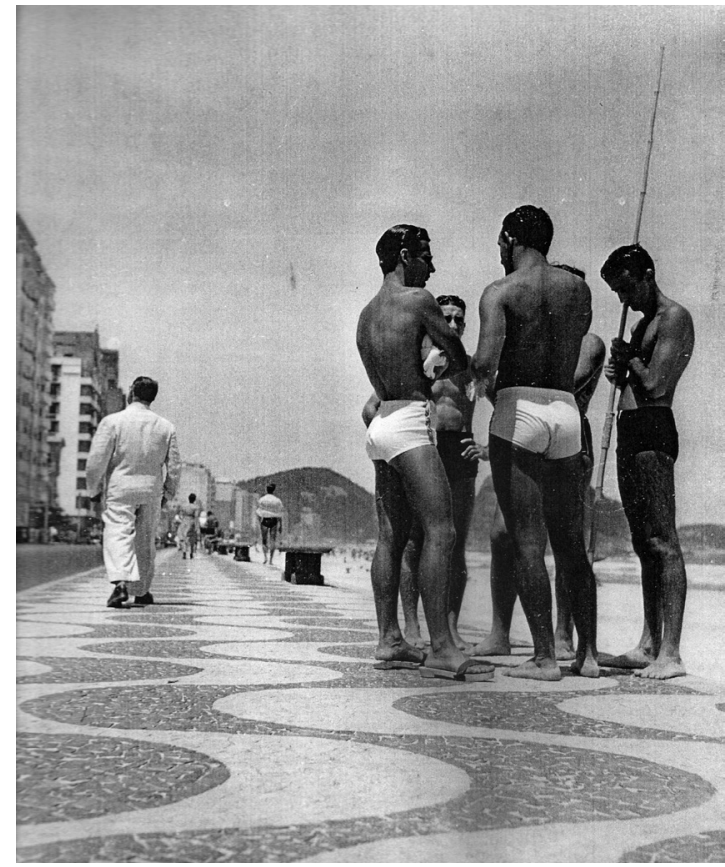

Figura 5 - Praia de Copacabana, Rio de Janeiro, 1941, Genevieve Naylor, coleção Peter Reznikofo.

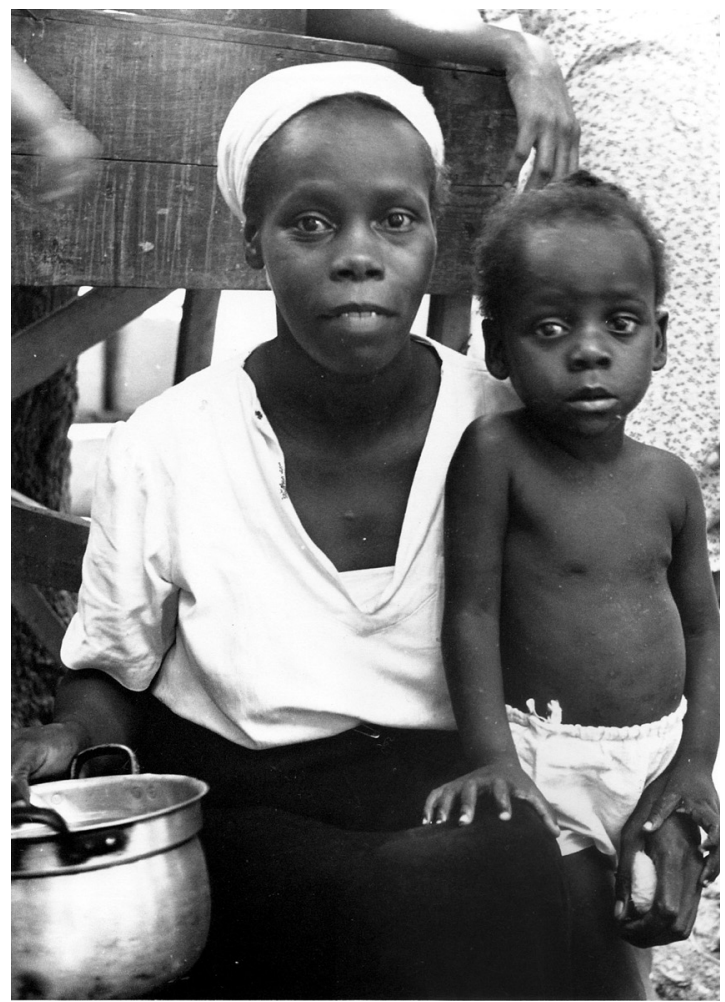

Figura 7 - Mãe e filha, Rio de Janeiro, 1941, Genevieve Naylor, coleção Peter ReznikofC.

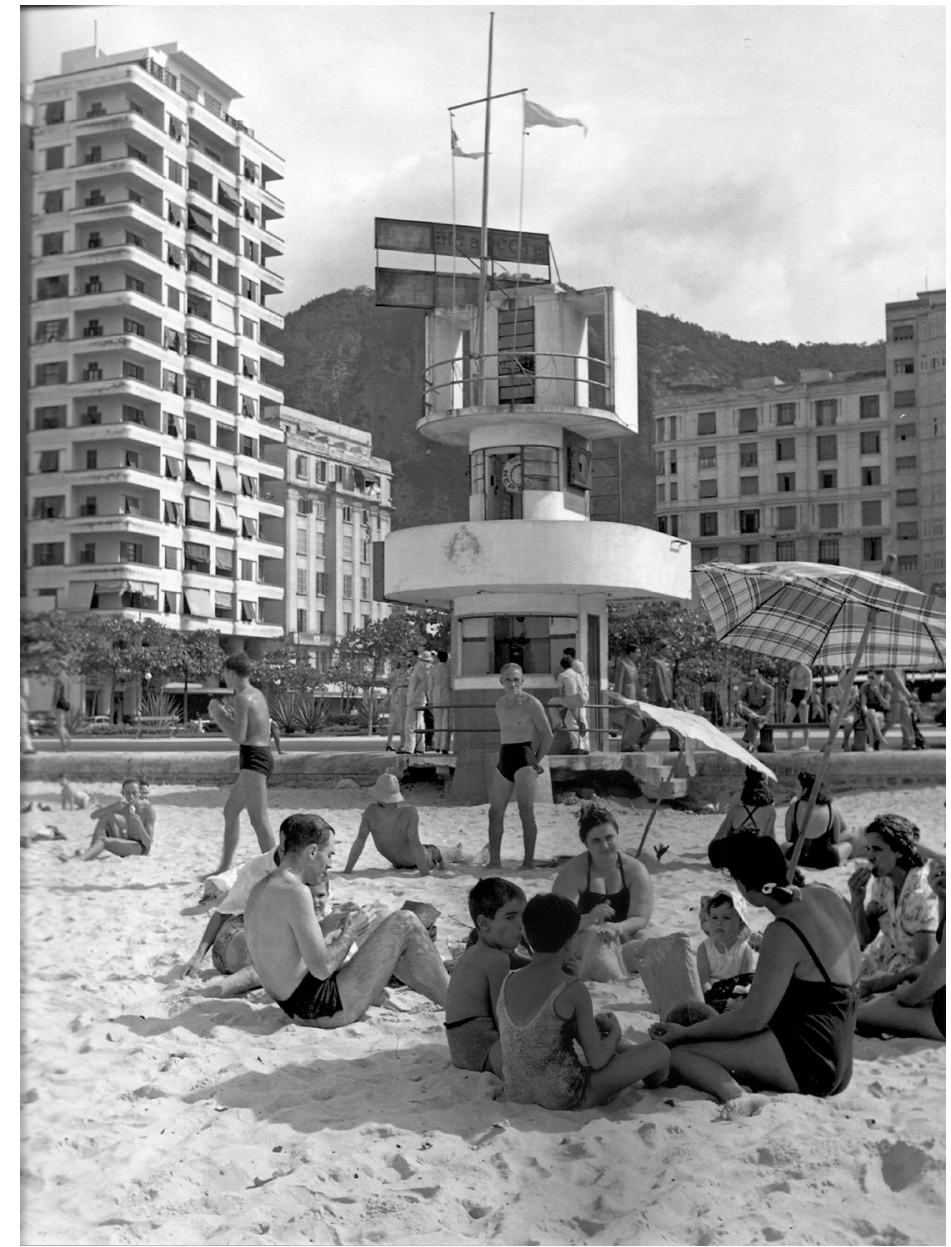

Figura 6 - Praia de Copacabana, Rio de Janeiro, 1941, Genevieve Naylor, coleção Peter Reznikof@.

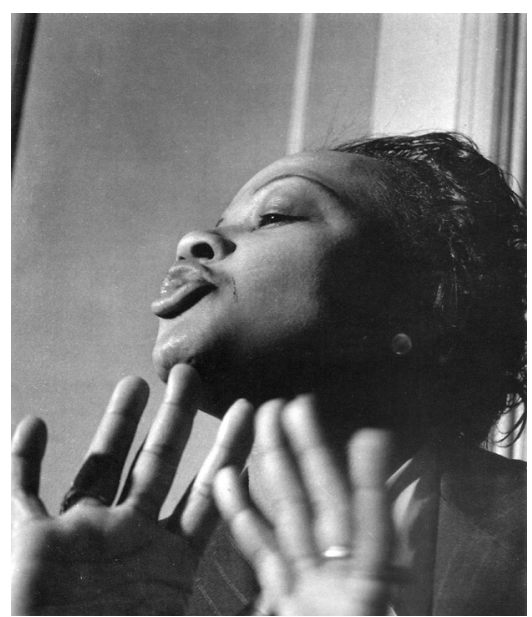

Figura 8 - Cantora de samba, Rio de Janeiro, 1941 , Genevieve Naylor, coleção Peter Reznikoł@ .

Anais do Museu Paulista. v. 22. n.1. Jan.-Jun. 2014. 
Vários estudos chamam atenção para o fenômeno cultural denominando de Harlem Renaissence, transcorrido entre os anos 1918 e 1948, do qual surgiram os ícones da cultura afro-americana e uma ambientação sofisticada para seus personagens:

The words "Harlem Renaissance" conjure up vivid images: Duke Ellington and Cab Calloway at the Cotton Club, flappers in beads and scarves, Bessie Smith's winsome smile, Langston Hughes looking elegant and solemn at his writing table, Josephine Baker in feathered dance costumes, W.E.B. Du Bois looking confidently into the camera lens. But the black renaissance and cultural revolution that took place in Harlem, New York between the World Wars was much more than these images. It was a profound literary and political movement as well 21 .

Esse movimento de valorização cultural no Harlem não se limitou às estrelas da música e do teatro. Ao longo da década de 1930, como forma de fazer frente ao desemprego, o governo dos Estados Unidos agenciou vários projetos para empregar artistas e promover as artes; dentre eles destacou-se, para a cidade de Nova York, no âmbito do WPA, um programa cultural abastecido pela abundante produção afro-americana no âmbito da literatura, performance e expressão visual que permaneceu até o início dos anos 1940. $\bigcirc$ (re) nascimento de uma cultura afro-americana eminentemente urbana, sofisticada e internacionalmente reconhecida atraiu vários artistas e intelectuais para o Harlem, inclusive brancos, convivendo numa Nova York dos anos 193040 que valorizava a experiência multirracial.

É nesse contexto, como artista comissionada pelo programa cultural do WPA, que Genevieve Naylor, aos 22 anos, registrou o cotidiano de ensaios e atividades dos estúdios de dança e teatro do Harlem. Nesse trabalho, Naylor ainda está em fase de treinamento de seu olhar para lidar com a relação entre - sujeito e a situação que ela quer produzir fotograficamente. Na sequência de uma de suas folhas de contato (Figura 9), as imagens demonstram um exercício próprio dos fotógrafos que trabalham tanto com filmes de $35 \mathrm{~mm}$ quanto com chapas em formato quadrado (típicas da câmera Speed Graph, que ela utilizava), em que se apresenta a sequência do ato fotográfico. A busca de uma imagem-síntese que condense o sentido daquilo que foi visto está latente, no quadro a quadro dessa folha de contato, em que também se expressa o exercício de ver continuadamente, subvertendo a segmentação própria da câmera fotográfica e compondo uma narrativa do que foi visto. Nas imagens abaixo não se sabe a que foi efetivamente escolhida para publicação, mas se entra em contato com uma espécie de intimidade visual da fotógrafa, só revelada em situações especiais como no exame das folhas de contato dos fotógrafos, a que poucos têm acesso 22 .

Por meio desse conjunto de imagens assumimos o ponto de vista da fotógrafa que, mesmo pertencendo à elite branca do norte dos Estados Unidos, teve acesso habilitado ao bairro negro de Nova York e registrou o cotidiano de
21. Informações retiradas no site <http://www.pbs.org/ n e w s hou r/foru m / february98/harlem_2-20. html>, em 28 de maio de 2010. A PBS Newhour é um site de notícias que promove debates sobre assuntos diversos e o tema do fórum em questão era justamente o renascimento do Harlem e a cultura afro-americana; dele participaram acadêmicos representativos das ciências sociais e das artes, dentre os quais: Jeffrey C. Stewart, professor de história no George Mason University; William Drummond, jornalista e professor na University of California at Berkeley, e Richard Powell, professor associado de Artes e História da Arte na Duke University e co-curador da exposição Rhapsodies in Black, organizada no California Palace of the Legion of Honor in San Francisco; ver, sobre essa exposição, o sítio <http://www.iniva.org/ harlem/index $2 . \mathrm{html}>$, acesso em 13 de maio de 2014 .

22. Uma vez mais agradeço a Peter Reznikoff a oportunidade de ter acesso aos arquivos de Genevieve Naylor e à sua intimidade fotográfica. Sem a generosidade de Peter Reznikoff, ficaríamos todos privados dessa proximidade que a folha de contato nos oferece em relação ao olhar de Naylor. 


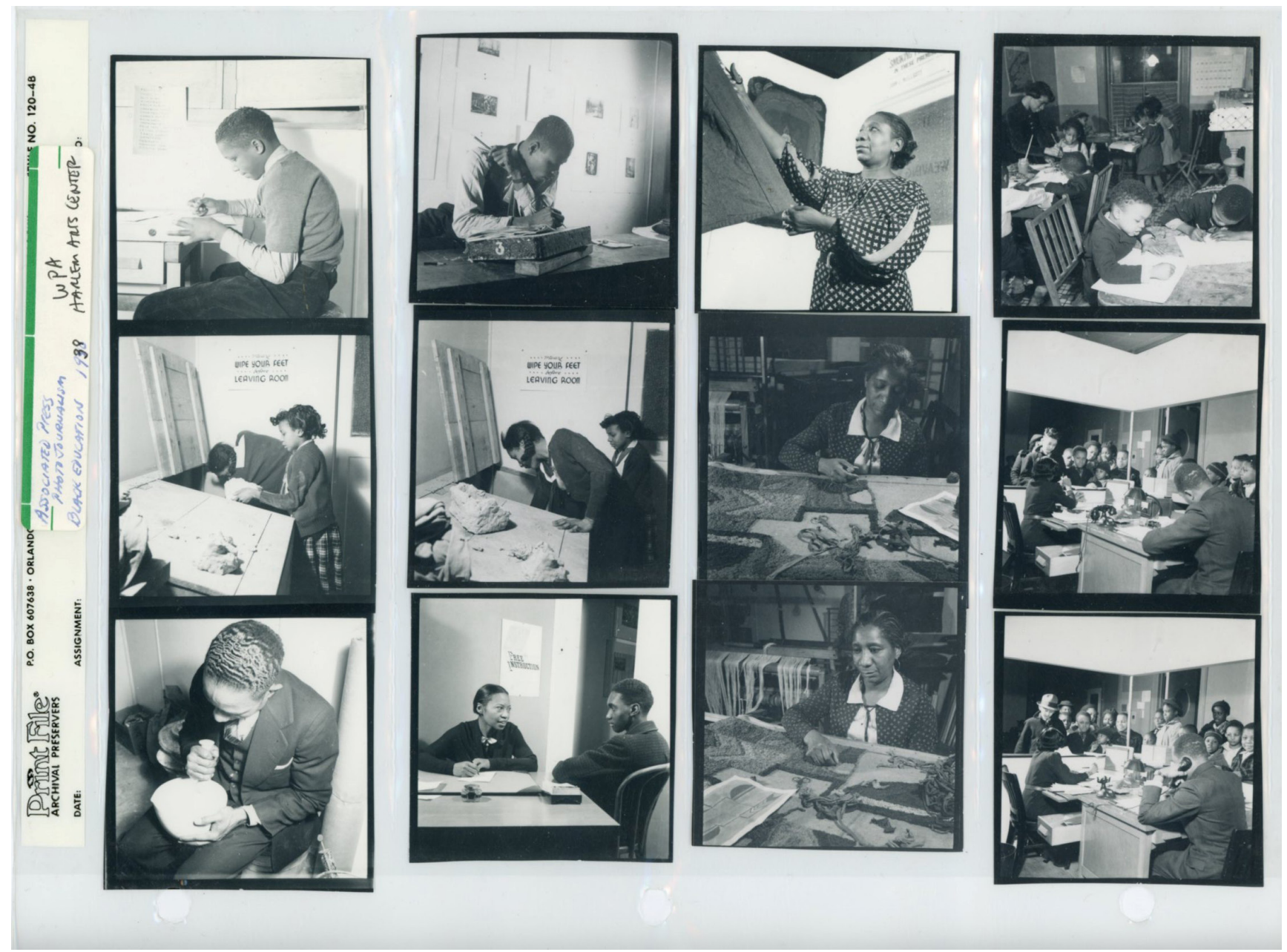

Figura 9 - População Afro-americana engajada em atividades artísticas no bairro do Harlem, Nova York, c. 1939, Genevieve Naylor, coleção Peter Reznikof@.

jovens e crianças. No conjunto se observa a adoção de um padrão de representação em que a juventude negra se apresenta em atividade, de forma ordenada. No entanto, a abordagem visual delineada pela proximidade da tomada da foto e pelo tipo de enquadramento, o tradicional plano médio americano (da cintura para cima), denota que a fotógrafa se misturava com o grupo fazendo com que seu trabalho e ela mesma integrassem a mesma comunidade. Em todas as imagens, os jovens realizam algum tipo de atividade que, se não fosse pela inclusão das anotações da fotógrafa na lateral da folha de contato, não conseguíamos interpretá-las. Pelos comentários, descobrimos tratar-se do Harlem Arts Center e que foi fotografado no âmbito do WPA. Essas imagens são evidências de que o renascimento do bairro foi apoiado por projetos do New Deal, como da própria economia visual que as produziu, fazendo parte de uma atividade fotográfica engajada na reconstrução do país. 
Brasileiros, afro-brasileiros e bons vizinhos.

Naylor foi recebida no Brasil pela fina-flor das artes, da intelectualidade e da boemia; no seu caderninho de endereços constavam nomes ilustres, como Portinari, Murilo Mendes, Heitor Villa Lobos, todos fotografados por ela, mas também incluía os que ainda viriam a adquirir grande notoriedade, dentre eles dois interlocutores - Vinicius de Morais e Aníbal Machado ${ }^{23}$ - que apresentaram a fotógrafa, em suas crônicas, ao público carioca. Vinícius de Morais a identificava com personagens das histórias de Hobin Hood, por conta do chapéu que protegia a pele branca da fotógrafa do sol tropical:

Genevieve parece ter saído de uma história de Robin-Hood, com seu arzinho de jovem pajem, sua elegância bem colorida, uma pena sempre atrevidamente espetada no chapéu. Nada escapa, no entanto, à maquinazinha dessa enfeitiçada. Perto dela não há momento fotográfico que passe sem cair naquela arapuca bem armada. Genevieve dá um pulinho -e a vida ali ficou batendo asa na sua chapa impressionada ${ }^{24}$.

Aníbal Machado, por sua vez, que vizinho da fotógrafa e de seu marido no bairro do Leme, exaltava a forma realista que como Naylor fotografava:

Via-a saindo pela madrugada ou à noite, indiferente às intempéries, obstinada na realização de seu trabalho[...] Mais que a excelência técnica, o que é preciso louvar nos trabalhos de Miss Genevieve é o sentido sociológico com que ela utilizou a objetiva, revelando um espírito corajoso e sincero, e, não raras vezes, comovido diante da realidade brasileira [...] Os assuntos populares, humildes, os tais elementos essenciais que compõem a fisionomia do nosso povo são captados, pela fotógrafa da Boa Vizinhança. Mas sua maneira de fixar a realidade nada tem de monumental. Nada de cachoeiras, de edifícios monumentais, de paisagens idílicas. Sua visão poético-sarcástica por vezes evoca a arte sul-realista. Um país - O Brasil - captado então na sua força real: assim, no carnaval, a alegria é antes uma vibração convulsiva da tristeza que procura atordoar-se...como se estivesse procurando o resumo etnográfico. Importante o olhar, a percepção das imagens simples, que permite a recuperação dos tempos históricos acomodados no cotidiano, mas que resgata a vida de cada um em sua profundidade e intensidade. Não raro surge uma imagem agônica, áspera porém silenciosa, sempre densa. "Nada de cachoeiras... ${ }^{25}$.

Em outubro de 1940, aos 25 anos de idade, Naylor chegara ao Brasil portando duas câmeras, um medidor de luz, e uma surrada maleta de vime negro. Sua primeira impressão foi registrada em carta a sua irmã:

My first striking visual sight was not the bustling energy of the Copacabana beach or the boulevards and slums, but a solitary young Negro girl sitting cross-legged in the center of a street, intensely focused on constructing a wooden flute. If there ever was a moment to have my camera! Unfortunately, the Brazilian authorities have confiscated my equipment while they scrutinize my back ground to make sure I'm not some fifth-columnist subversive! ${ }^{26}$.

Assim que chegou ao Rio, Naylor recebeu instruções claras do DIP sobre o que deveria fotografar. $\bigcirc$ documento indicava que a fotógrafa precisaria valorizar
23. Vinicius de Moraes (1913-1980), nascido no Rio de Janeiro, estudou Direito mas se consagrou como poeta e compositor. Anibal Machado (1894-1964), nascido em Minas Gerais, também estudou Direito mas se notabilizou como escritor e teatrólogo; radicou-se no Rio de Janeiro desde 1924, onde foi responsável pela montagem de obras teatrais e organizacão de importantes grupos ligados ao teatro experimental.

24. Cf. Vinícius de Moraes (19/10/1941).

25. Cf. Aníbal Machado (28/12/1941).

26. Carta de Naylor para sua irmã Cynthia Gillipsie, Rio de Janeiro, n.d., acervo de Peter Reznikoff, a quem agradeço a cortesia de permitir a consulta. 
27. Refiro-me a Gente Bamba, de Synval Silva, datada de 20/03/1937 e Quem condena a batucada, de Nelson Petersen, datada de $1 \% / 08 / 1938$.

28. Sobre o debate em torno da problemática da definição da cultura brasileira nos marcos do processo de mundialização do século XX, ver: Renato Ortiz $(1994,1989)$. alguns temas, dentre os quais: arquitetura moderna (principalmente prédios governamentais); casas dos bairros nobres, como Lagoa, Gávea e lpanema; interior de casas importantes e elegantes, no bairro do Flamengo; os domingos de sol nas praias de Copacabana e Ipanema; as corridas de cavalo no Jockey Club, os veleiros e iates na baía de Guanabara, o comércio exclusivo da Rua do Ouvidor e as obras de caridade da Primeira Dama, Dona Darcy Vargas.

O casal circulou na boemia carioca como também na alta sociedade, alcançando um contato ampliado com a população da capital fluminense. Como o casal chegou antes de outros norte-americanos enviados pelo Office, ambos acabaram atuando como ponte entre o Brasil e os recém-chegados dos EUA. Orson Welles, por exemplo, pediu a Genevieve Naylor que the ajudasse a encontrar locações para o documentário que iria filmar aqui no Brasil. Sobre a vinda de Welles, Naylor escreveu à irmã: "Welles knew the obvious spots, but he didn't know that in Praça Onze a separate and almost exclusive Negro carnival is staged". Tanto Welles como Naylor ficaram encantados com a cultura popular brasileira, indo contra as recomendações oficiais de apenas produzir uma imagem do brasileiro como ordeiro e trabalhador. No entanto, ao contrário de Welles, Naylor foi mais discreta na sua desobediência, além de evitar a publicidade de que Welles tanto gostava.

Dos temas retratados por Naylor, destacam-se as imagens do Rio de Janeiro, então Capital Federal, como o espaço no qual a experiência multicultural brasileira foi visualizada pelo olhar da fotógrafa. Neste artigo, foram escolhidas as imagens de carnaval que valorizam a presença negra no espaço da cidade e fornece realce a sua performance cultural, que são compreendidas como análogas àquelas outras em Naylor registrara a cultura negra valorizada pelo movimento Harlem Renaissence.

Para interpretar a leitura visual feita pela fotógrafa, foram associados às suas fotografias alguns textos que circulavam na época em ela esteve no país e que podem ter sido lidas por Naylor quando da sua estadia aqui. Primeiramente, alguns comentários e opiniões que Vinicius de Morais publicou em suas crônicas no jornal A Manhã, entre 1941 e 1942, quando da vinda de Orson Welles ao Rio. Outro grupo de textos é composto por dois sambas de fins dos anos 193027, cantados por Carmem Miranda e que exaltavam, em suas letras, aspectos característicos ou atribuídos à cultura negra carioca, tais como o samba, o corpo bronzeado, o gingado, a alegria; e também a tradição, a ascendência aos povos antigos da África. Tais características foram cimentadas na elaboração de uma musicalidade tida como legitimamente brasileira, com os quais se passava a delimitar os sinais de fusão entre o nacional e o popular ${ }^{28}$.

Quando Orson Welles chegou ao Brasil em 1941, o então cronista e crítico de cinema Vinicius de Morais revelou seu entusiasmo nas páginas do periódico no qual escrevia - A Manhã. A excitação só aumentou depois que o futuro poeta conhece o jovem cineasta e revela: "Só tenho vontade de pegáto e levá-lo a ir comer um tułu com linguiça na casa da gente, apresentá-lo a família, 
ficar amigo dele. Esquece-se mesmo da grandeza da sua missão artística [...]"29. Um dos destaques da missão artística de Welles era o de, justamente, filmar o carnaval do Rio, como explica, na mesma crônica, Vinicius de Morais:

Seu novo filme, onde entra o Carnaval carioca - e eu quero ver o que vai sair dali para depois crer, pois trata-se de um malfadado tecnicolor - e em que deposita as maiores esperanças: seu entusiasmo pelo Brasil, onde ele quase nasceu; suas idéias sobre interpretação negra, que ele julga tão boa como a branca, quiça superior, pois se revela através de uma natureza mais pura, menos manchada por isso ele chama de XIXth century's romanticism; seus broadcasts sobre o Brasil, para os Estados Unidos. E isso tudo faz o homem ${ }^{30}$

Em outro momento, Morais comenta o encontro com o pessoal da missão, numa visita que fez com Welles aos estúdios da Cinédia. Nesse encontro estavam Misha Reznikoff, marido de Naylor, o escritor Aníbal Machado, além de Orson Welles. A conversa correu animada e a questão racial brasileira nos anos 1940 foi o ponto alto do debate, como sintetiza Vinicius de Morais:

Conversou-se muito. Conversa que não daria para uma crônica, mas para muitas, algumas das quais não sei se lógicas. Orson Welles está consciente da verdade do seu esforço, e disse-me que se o filme não sair bom a culpa não terá sido dele. Falar a verdade, é difícil saber o que vai ser exatamente esse filme seu. Mas de qualquer modo será um documentário da maior importância sobre a nossa verdadeira vida e nossos verdadeiros costumes, que eu acho não devem envergonhar ninguém. Não somos uma raça, e não devemos pejar disso. O nosso negro é um valor excelente, e de grande expressão. Não há razão para escondê-lo, criando-se a impressão de que temos um preconceito que não nos cabe na nossa natureza de povo americano. Devemos nos mostrar tal como somos, tal como fomos feitos. Por que, se alguma coisa de boa deve sair do Brasil, virá dessa consciência de nossa impureza e do nosso provincianismo. Há um destino a cumprir em cada povo. $\bigcirc$ Brasil se apronta para cumprir o seu. Mas que o faça sem couraças adamantinas, que não the vão bem no corpo mestiçado ${ }^{31}$

Povo mestiçado, negro como valor, carnaval como cultura, isso tudo foi retratado por Naylor. A fotógrafa conseguiu realizar o que Welles deixou sem finalizar, pois não concluiu o filme que veio filmar no Brasil. Naylor compôs o retrato de um Brasil plural enquadrado pelas lentes fraternas da boa vizinhança, não como política de Estado, mas como poder de sedução da cultura política.

De volta aos Estados Unidos, no final de 1942, Naylor apresentou a exposição Rostos e lugares do Brasil no MOMA-NY, que seria inaugurada em 1943. Dentre os sete temas definidos pela curadoria da exposição, para organizar as 50 imagens escolhidas, o carnaval foi um deles:

7. Carnival. This gay section shows the high point of the Brazilian year, the famous Carnival (of Rio) in which the entire nation participates. From Samba schools situated in the mountains where the very poor lives come groups of children who for months have practiced Samba songs for the Carnival, where prizes are awarded. The photographs show Samba musicians in the elaborate silk and satin costumes they have designed for themselves; boys and girls in
29. Cf. Vinícius de Morais (30/04/1942)

30. Idem

31. Idem 
32. Press release Photography exhibition Faces and Places in Brazil. The Museum of Modern Art Achives, Nova York, CUR 215.

33. Para visões distintas sobre o tema das relações étnico-raciais entre o Brasil e os Estados Unidos, ver. Antônio Risério (2012), Antônio Sérgio Alfredo Guimarães (2009) e Lilia Schwarcz (2012). Para uma abordagem consolidada sobre a questão da cidadania no pós-abolição e os debates sobre a fronteira fluída entre cativeiro e liberdade no século XIX e sua memória no Brasil, ver Hebe Mattos (2013). ordinary street clothes twirling small paper parasols as they dance Samba; women with all sizes and shapes and colors loaded with ornaments and flowers; and even store Windows through which smile wooden manikins carved and pained realistically and dressed in Carnival costume ${ }^{32}$.

Apesar de não estar arrolado entre os temas fotografáveis pelo DIP, o carnaval, como festa popular, foi identificado como expressão propriamente brasileira pelas lentes da boa vizinhança. No entanto, o trabalho intertextual revela as contradições que orientaram as representações da cultura afro-brasileira nas músicas, crônicas e imagens fotográficas na elaboração no imaginário social do Brasil dos anos 1940.

As imagens do Carnaval carioca de 1942, produzidas por Genevieve Naylor, reúnem $12 \%$ das fotografias da amostragem e compuseram, como foi dito, uma seção da exposição de 1943. Desse conjunto, em 99\% das imagens foram retratados afro-brasileiros de diferentes idades e gênero, dançando fantasiados, em grupos, pelas ruas da cidade, pela manhã ou à noite, tocando instrumentos de percussão em clubes, agremiações carnavalescos e nos desfiles de blocos pela cidade. Observa-se nessas imagens a posse do corpo em movimento e também do espaço público como elementos que se destacam na abordagem visual da fotógrafa, um contraponto ao corpo da juventude afro-americana, ordenado e encapsulado no Harlem Art Center.

Limitar-se a uma interpretação que opera por oposições não é suficiente para compreender a trajetória das imagens das populações afrodescendentes de ambos os países. Marcadas por lógicas de segregação distintas, oriundas de sistemas escravistas semelhantes, diferentes práticas de lidar com as relações étnico-raciais foram vividas no Brasil e Estados Unidos, com as consequentes, e peculiares, incorporações de suas populações negras no conjunto da nação, como comunidade imaginada. Não cabe aqui desenvolver esse debate, que é profícuo e se estende até a atualidade ${ }^{33}$. Entretanto, vale tomar as duas abordagens adotadas pela mesma fotógrafa como sintoma da maneira como a expressão fotográfica documental é tributária tanto da inscrição do fotógrafo no debate social, quanto da atribuição de sua experiência estética.

Naylor, nos Estados Unidos, se inscrevia numa cultura radical pela qual se valorizava as artes e a cultura negra ativista, e, portanto, orientou sua abordagem visual por uma estética ordenada pela valorização do sujeito no trabalho artístico. Já no Brasil, a forma como se inseriu no debate sobre a presença negra na sociedade brasileira, em estreito diálogo com a vertente do nacional-popular, orientou sua abordagem para valorizar os atributos da cultura afro-brasileira que, se a princípio seriam identificados pela estética do pitoresco, devido a sua associação à desordem do carnaval, no seu desdobramento subverteram essa lógica.

O principal elemento de subversão da estética do pitoresco foi a expressão visual adotada pela fotógrafa para registrar o corpo em movimento em espaços públicos e não ordenados pela lógica da produção. Os tipos de enquadramento apoiados em 
cortes secos na imagem sem respeitar a integridade da figura (Figuras 10, 11, 22 e 24), associados a um jogo de ângulos plongée e contre-plongée e à dinâmica da câmera ora para a direita ora para a esquerda, permitiram a valorização do movimento do corpo como dança e expressão artística (Figuras 17 e 18), mas também, dos cariocas como parte integrante de cenário do Rio de Janeiro, cidade conhecida internacionalmente pelo contorno dos morros (Figuras 11 a 15, 19 a 22). Agregou a sua expressão estética a utilização de iluminação artificial, própria aos ambientes de performance carnavalesca, que valorizou as sombras, tencionando a relação entre claro e escuro (Figuras 10, 11, 13, 14, 16, 21 a 24), numa franca alusão à linguagem cinematográfica em voga desde Cidadão Kane, filme dirigido por seu parceiro de política da Boa Vizinhança, o já mencionado diretor e ator Orson Welles.

A forma como Welles foi fotografado por Naylor (Figura 25) denota o diálogo entre a experimentação estética na fotografia e no cinema, pois apresenta um personagem confuso, desconfortável em seu terno, limpando o rosto suado, com o corpo coberto por confete, à frente de uma multidão de foliões anônimos. A composição em dois planos bem definidos, pelo contraste de luz e sombra, coloca em plano central o diretor, mas inclui no foco os foliões que observam a captura da imagem pela fotógrafa. Aqui, Naylor utiliza-se de um recurso próprio do cinema moderno, em que se incluem, numa mesma cena, distintos pontos de vista, o da fotógrafa que enquadra o diretor, o dos foliões que observam a fotógrafa e o do público que assiste a tudo no fora do quadro que limita a imagem. Uma foto-ícone que condensa a história.

Todos esses ingredientes visuais foram utilizados pela fotógrafa para valorizar o que o Brasil tinha, sob o ponto de vista da promoção oficial que ela encampava, de próprio na sua cultura: a presença negra atribuindo sentido a cultura popular. Destaca-se, portanto, nas imagens de Naylor de 1942, o protagonismo da população negra no carnaval brasileiro configurado como performance visual e políitica marcada pelo domínio do corpo em movimento e pela ocupação dos espaços públicos da cidade.

Em comparação com as fotografias produzidas por Naylor no Harlem, no âmbito do Work Progress Administration, as imagens do Brasil se orientam por uma nova forma de enquadramento. A escolha de ambientar as fotografias no Harlem em espaços ordenados pela disciplina do trabalho artístico confirmava a vocação do renascimento de uma área da cidade de Nova York, que passaria a integrar a geografia cultural da cidade. $\bigcirc$ posicionamento da fotógrafa, comissionada pelo governo para produzir uma documentação sobre o processo de revitalização do bairro, diferiu daquele adotado por ela em relação à cidade do Rio de Janeiro. $\bigcirc$ que nos permite considerar que o ambiente cultural em que a fotógrafa se inseriu foi fundamental para sensibilizar o seu olhar em relação às peculiaridades da população afro-brasileira. Conversas com intelectuais, frequência nas rodas de samba e a observação atenta e participante de Naylor foram elementos fundamentais para a configuração visual, proposta por ela, e que coloca as fotografias em estreito diálogo com produção cultural da época. 


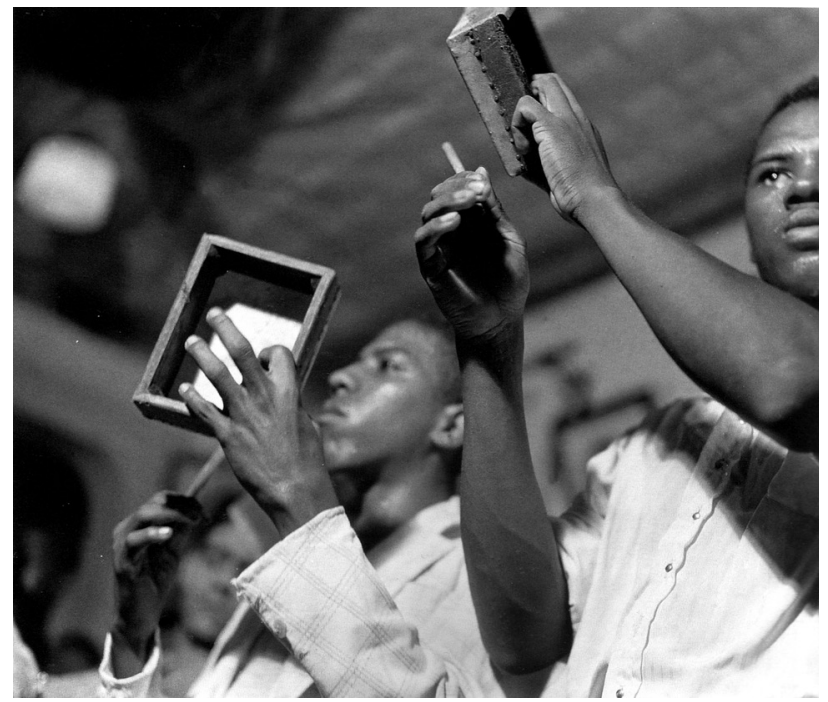

Figura 10 - Carnaval, Rio de Janeiro, 1942, Genevieve Naylor, coleção Peter ReznikofC.

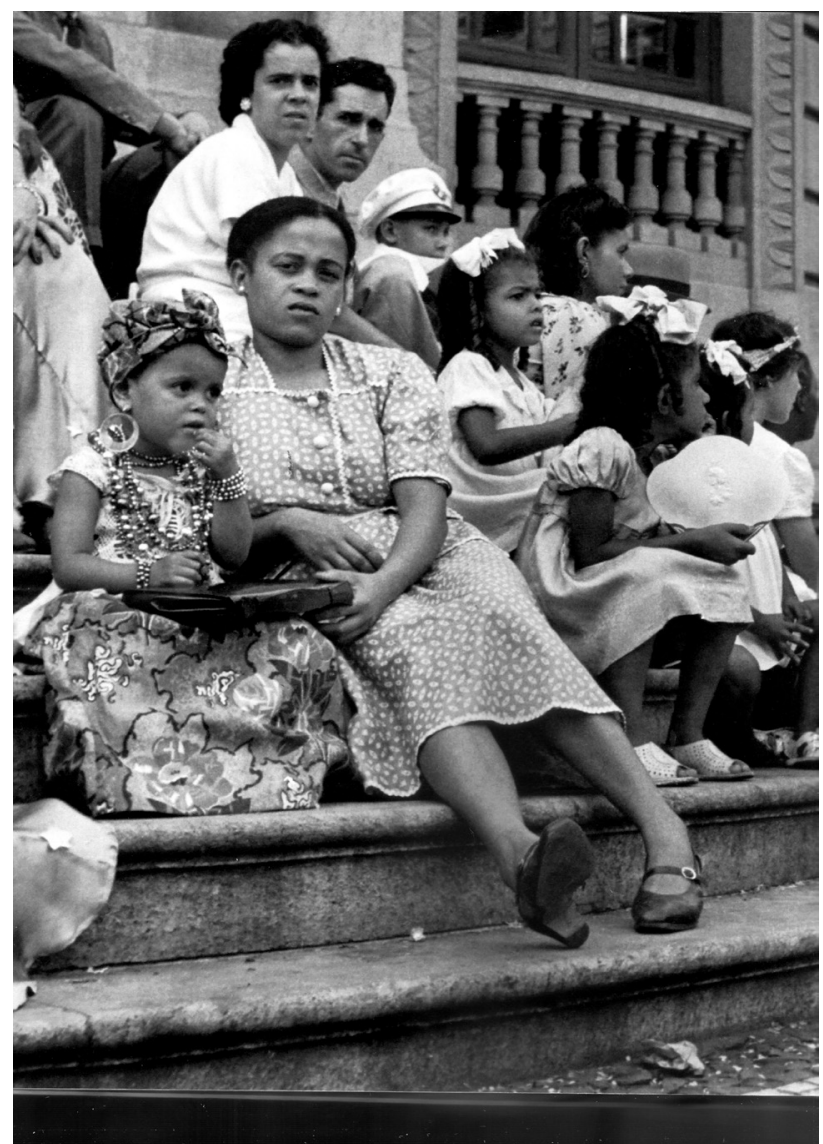

Figura 12 - Carnaval, Rio de Janeiro, 1942, Genevieve Naylor, coleção Peter ReznikofC.

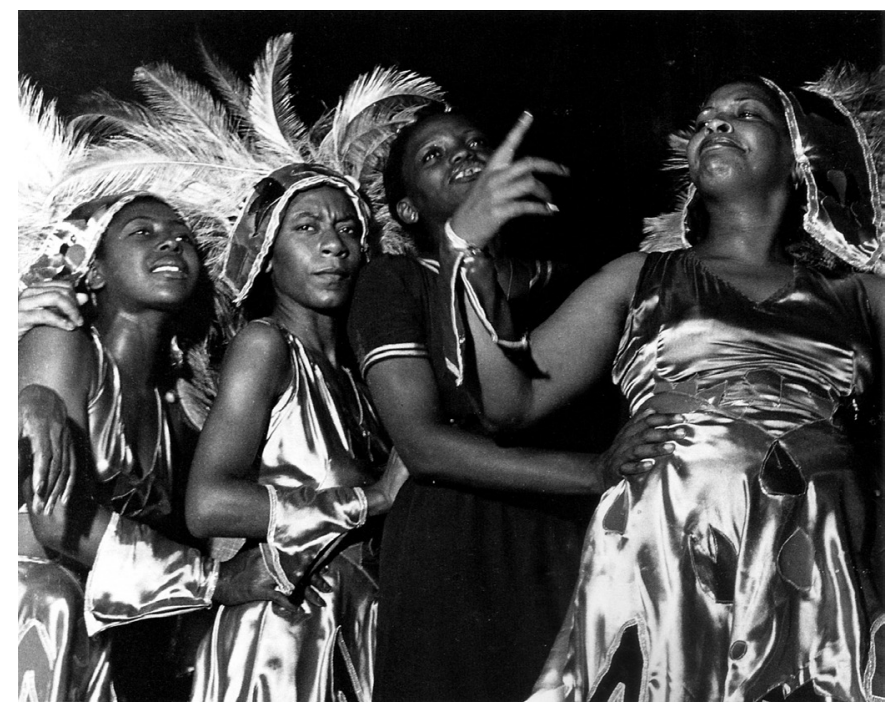

Figura 11 - Carnaval, Rio de Janeiro, 1942, Genevieve Naylor coleção Peter Reznikof@.

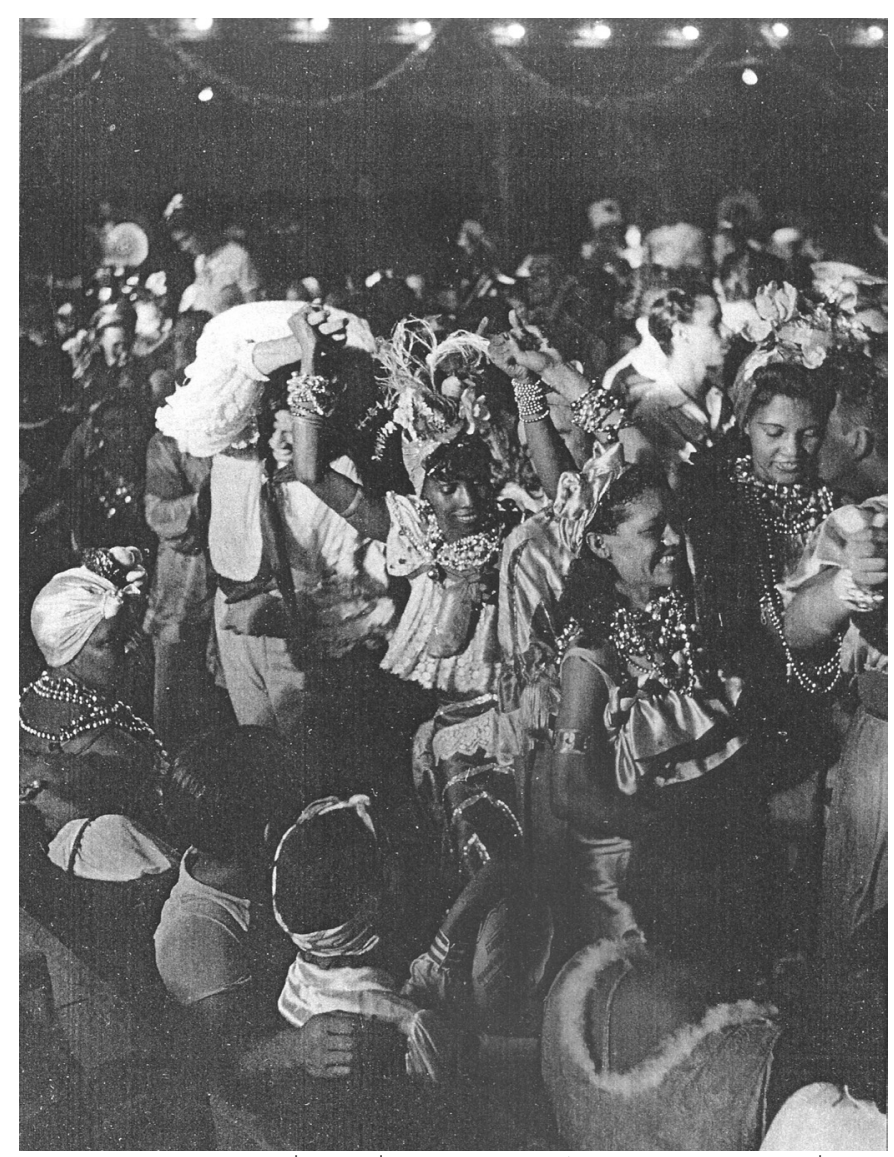

Figura 13 - Carnaval, Rio de Janeiro, 1942, Genevieve Naylor, coleção Peter ReznikofC.

Anais do Museu Paulista. v. 22. n.1. Jan.-Jun. 2014. 


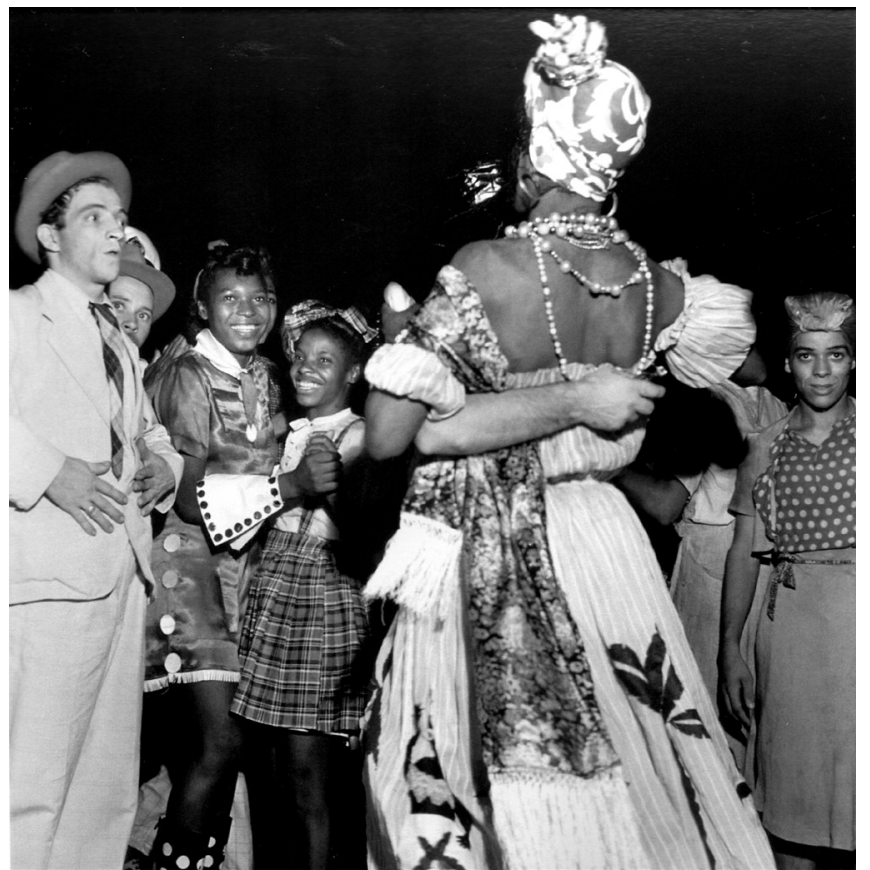

Figura 14 - Carnaval, Rio de Janeiro, 1942, Genevieve Naylor, coleção Peter Reznikof@.

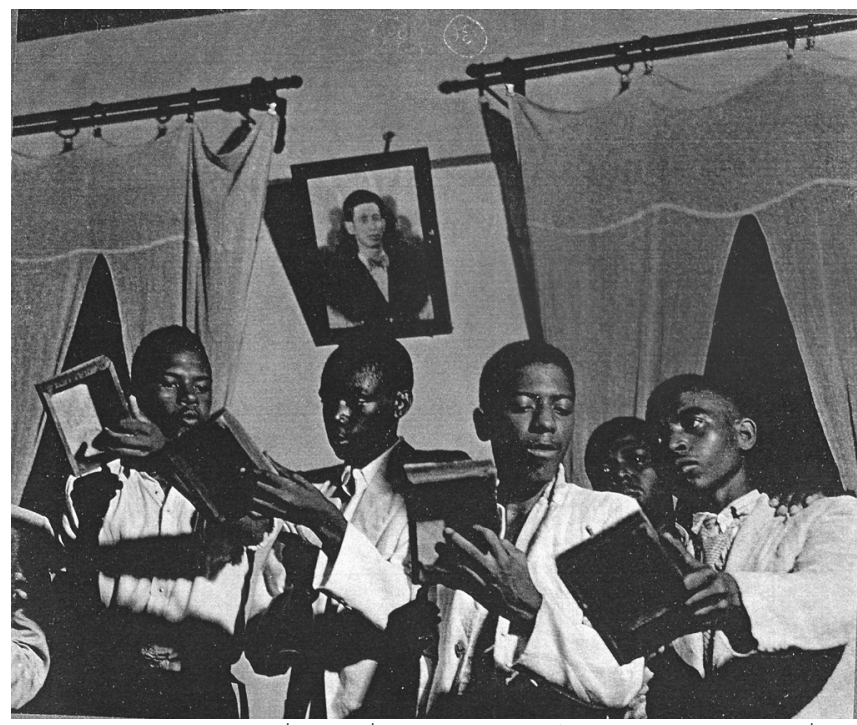

Figura 16 - Carnaval, Rio de Janeiro, 1942, Genevieve Naylor, coleção Peter Reznikof().

Annals of Museu Paulista. v. 22. n.1. Jan.-Jun. 2014.

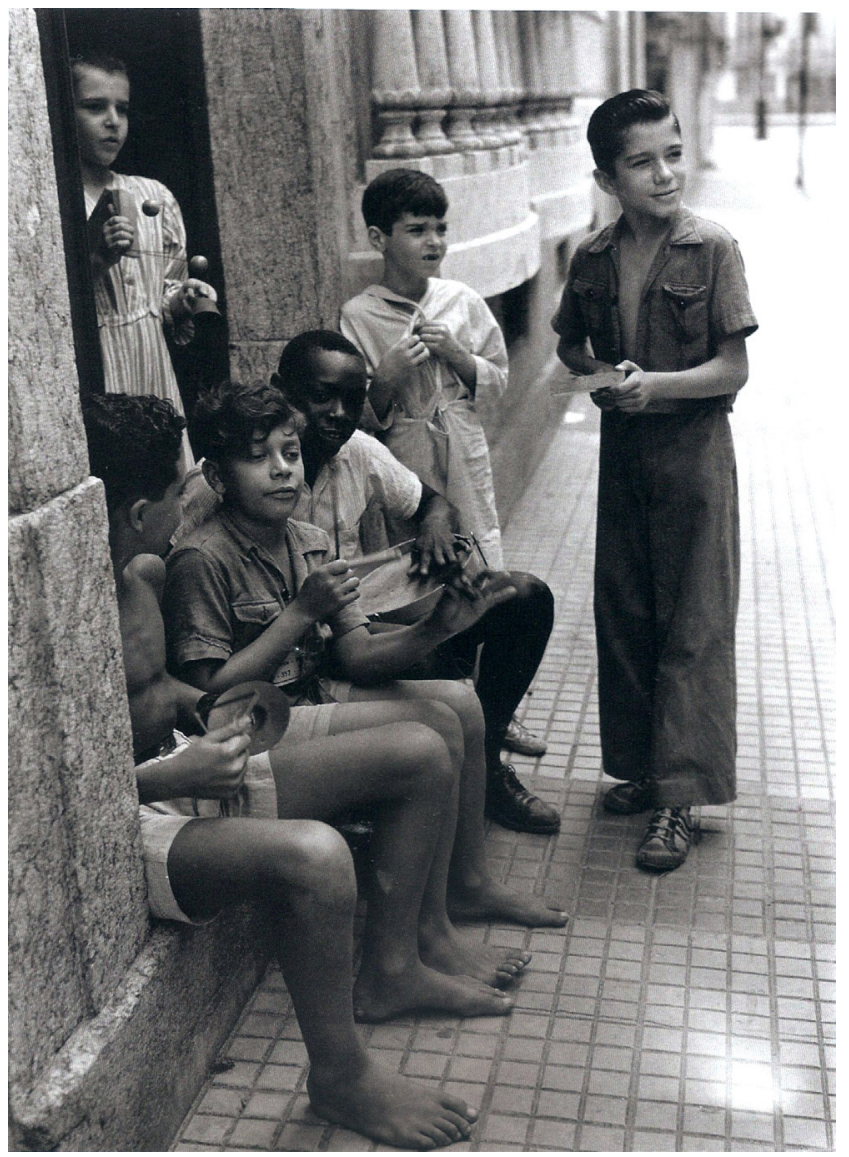

Figura 15 - Bairro de Leme, Rio de Janeiro, 1942, Genevieve Naylor, coleção Peter Reznikof().

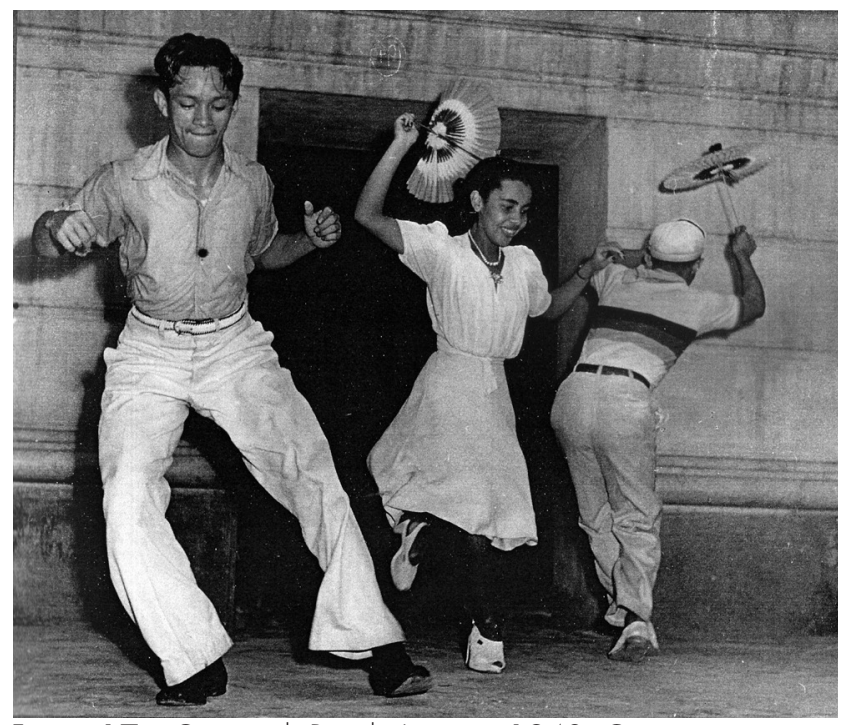

Figura 17 - Carnaval, Rio de Janeiro, 1942, Genevieve Naylor, coleção Peter Reznikoł@. 


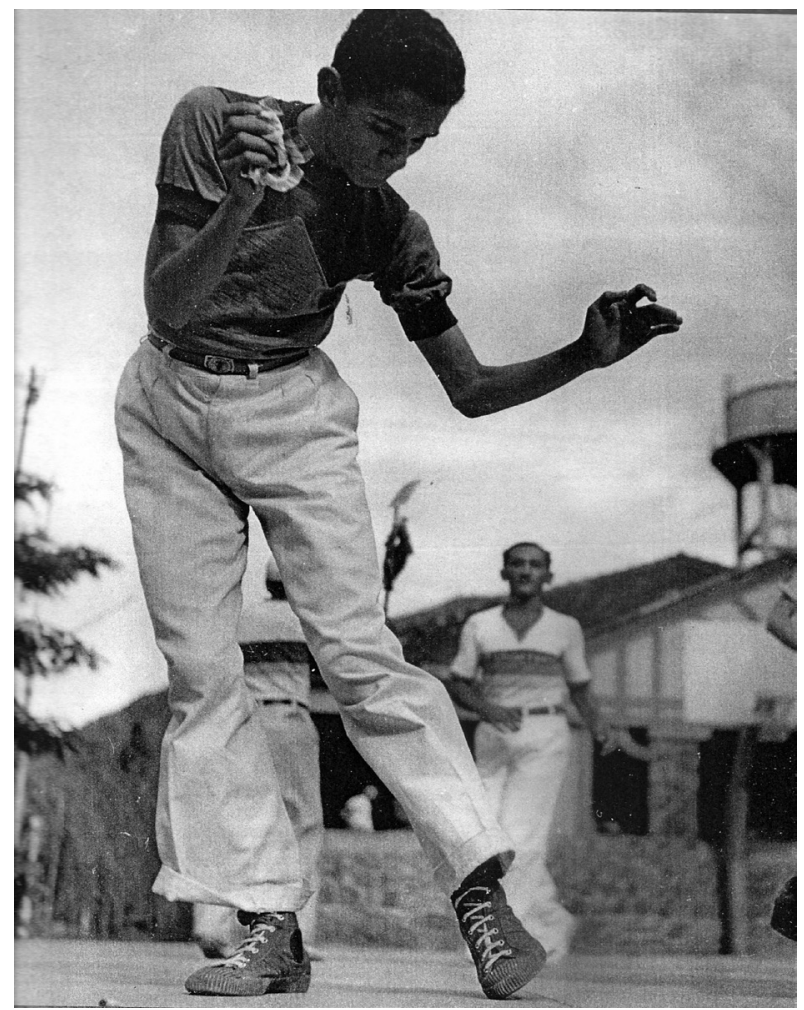

Figura 18 - Carnaval, Rio de Janeiro, 1942, Genevieve Naylor, coleção Peter Reznikof@.

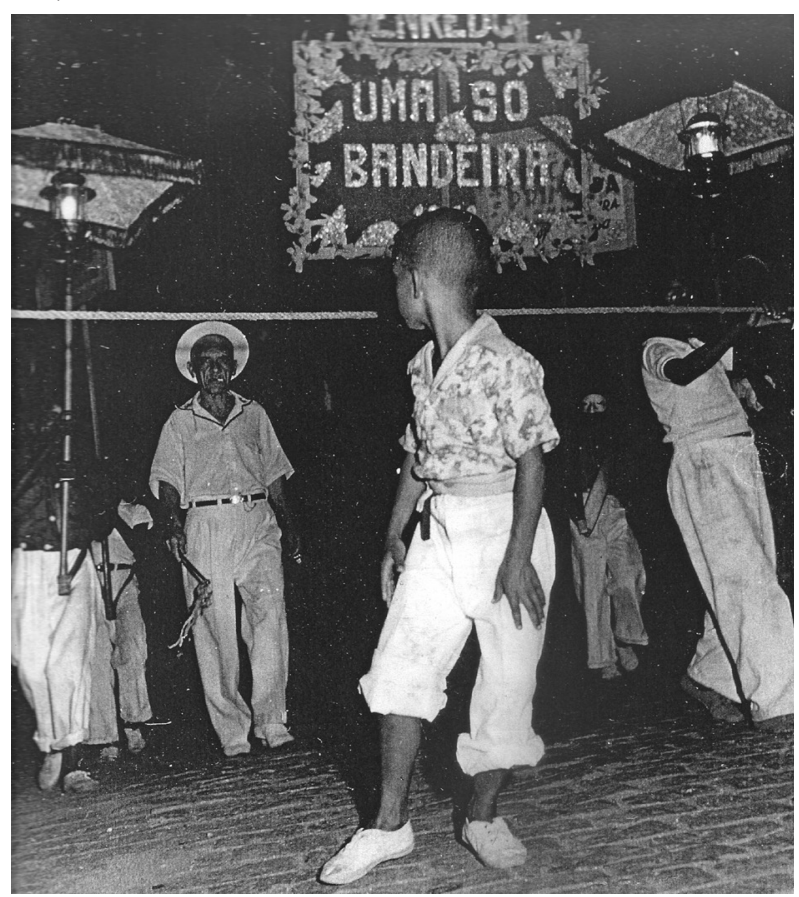

Figura 20 - Carnaval, Rio de Janeiro, 1942, Genevieve Naylor, coleção Peter Reznikof(o.

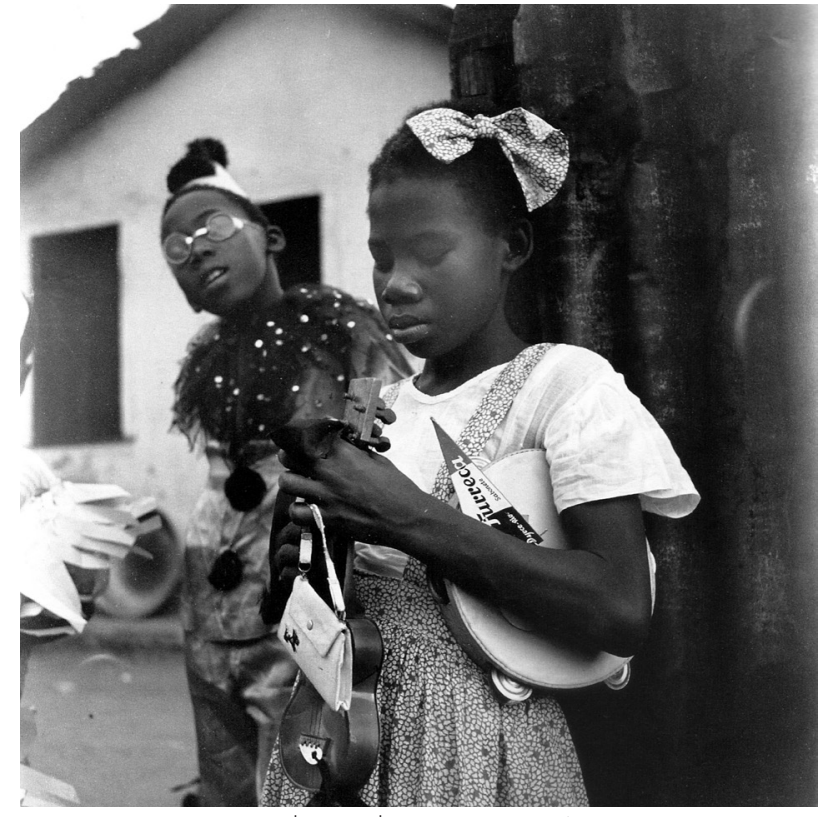

Figura 19 - Carnaval, Rio de Janeiro, 1942, Genevieve Naylor, coleção Peter Reznikofo.

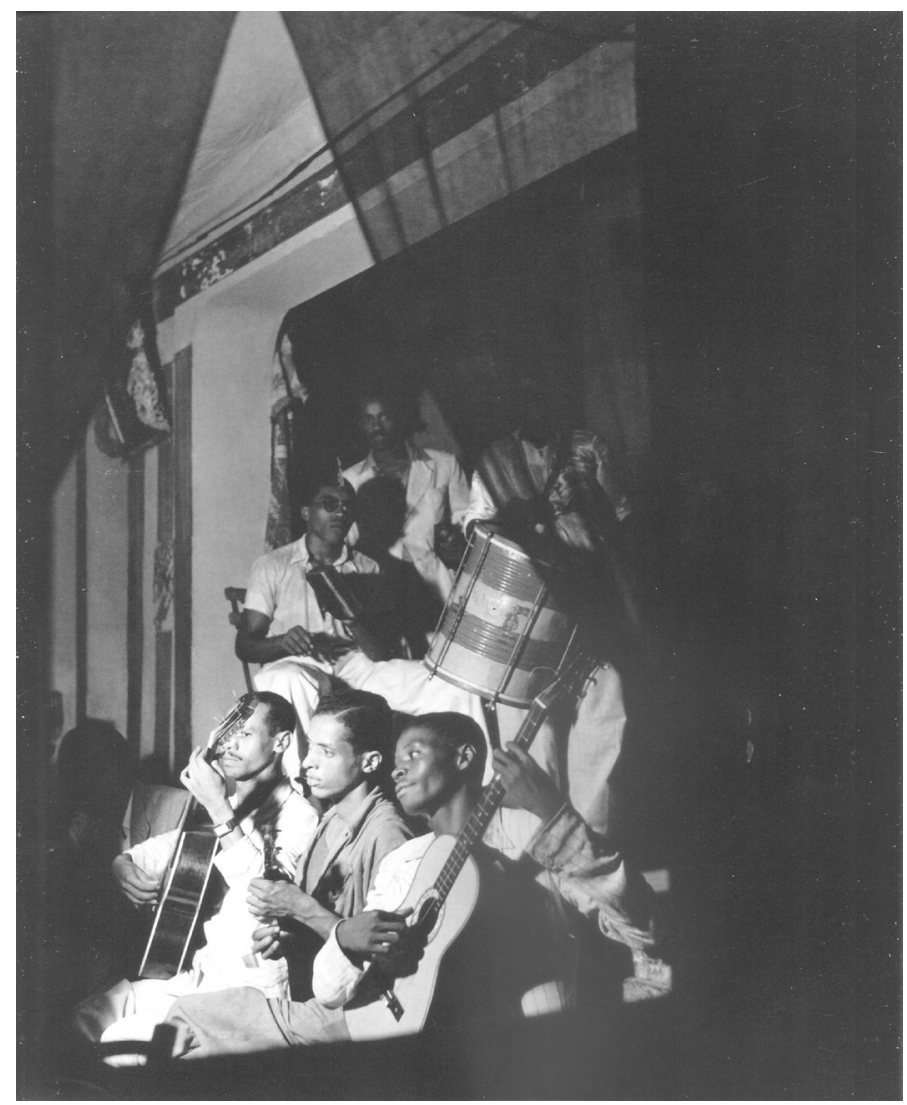

Figura 21 - Carnaval, Rio de Janeiro, 1942, Genevieve Naylor, coleção Peter Reznikof@.

Anais do Museu Paulista. v. 22. n.1. Jan.-Jun. 2014. 


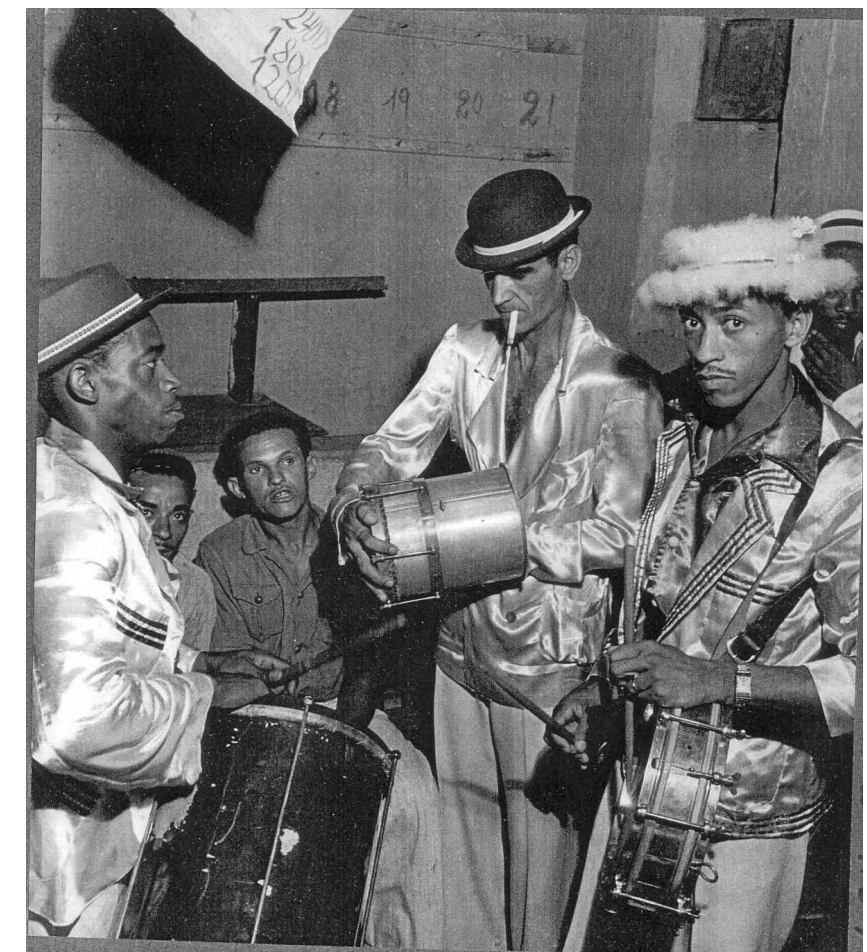

Figura 22 - Carnaval, Rio de Janeiro, 1942, Genevieve Naylor, coleção Peter ReznikofC.

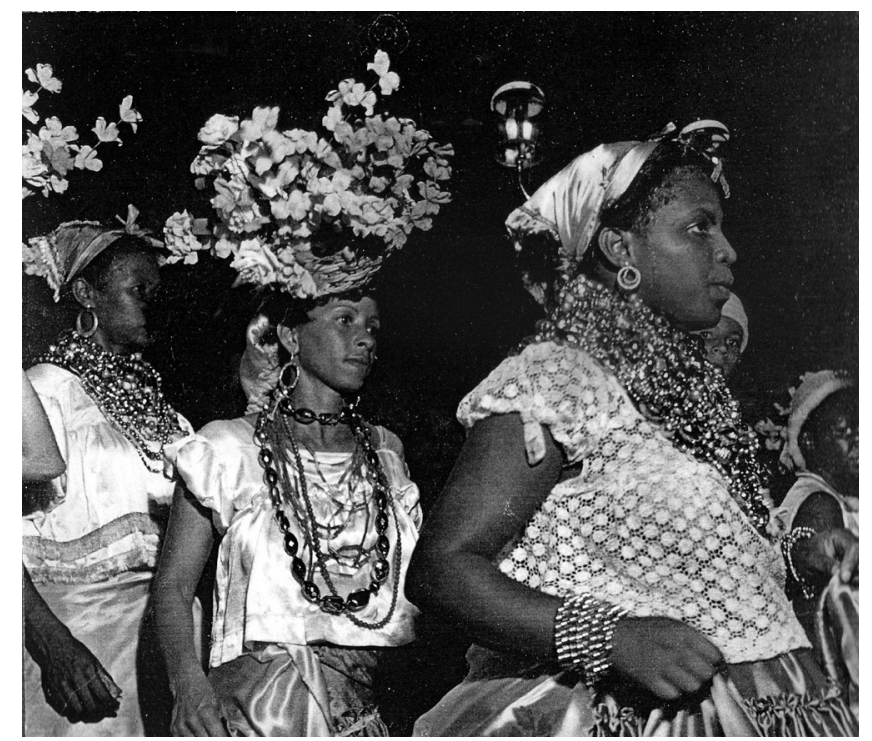

Figura 23 - Carnaval, Rio de Janeiro, 1942, Genevieve Naylor, coleção Peter Reznikofo.

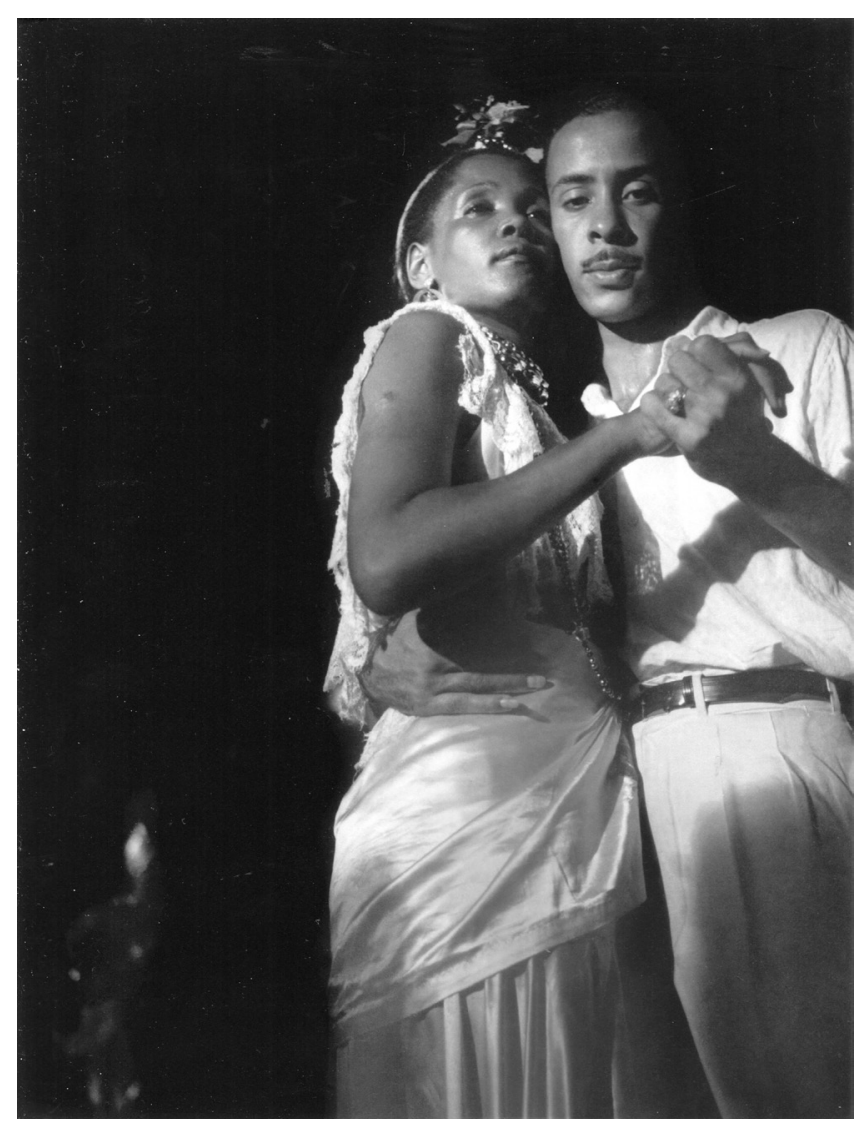

Figura 24 - Carnaval, Rio de Janeiro, 1942, Genevieve Naylor, coleção Peter Reznikofo. 
34. Ver Ana Maria Mauad (2002).

35. A "escrita videográfica" como resultado da pesquisa histórica implica na elaboração de um novo tipo de texto histórico que considere, na sua produção, a natureza do tipo de enunciação das fontes trabalhadas. Assim, para serem objeto de reflexão historiográfica e comporem o texto histórico, as fontes orais, visuais e sonoras devem ter sua substância de expressão preservadas. As estratégias de elaboração dessa nova modalidade de escrita da história contam com a ampliação do diálogo entre conhecimento histórico e produção audiovisual, por meio do trabalho em pareceria de historiadores e profissionais de cinema. Um trabalho no qual cada um colabora com o seu conhecimento e experiência numa produção coletiva que congrega as competências individuais. Sobre esse conceito ver: Ana Maria Mauad, Fernando Dumas e Ana Paula da Rocha (2006).

36. Acesso ao clip disponível em <www.historia.uff.br/ labhoi>.

37. "Assis Valente (19111958), nasceu, segundo seu relato, em plena areia quente, no caminho de Bom Jardim a Patioba, na Bahia, durante uma viagem de sua mãe. Teve uma infância conturbada, tendo sido roubado dos pais - José de Assis Valente e Maria Esteves Valente - e entregue depois a uma família para ser criado. Em Salvador, trabalhou como farmacêutico, fez cursos de desenho no Liceu de Artes e Ofícios e profissionalizou-se como especialista em prótese dentária. Transferiuse para o Rio de Janeiro, em 1927 e empregou-se como protético. No início dos anos 1930, começou a compor sambas. Em 1932, conheceu

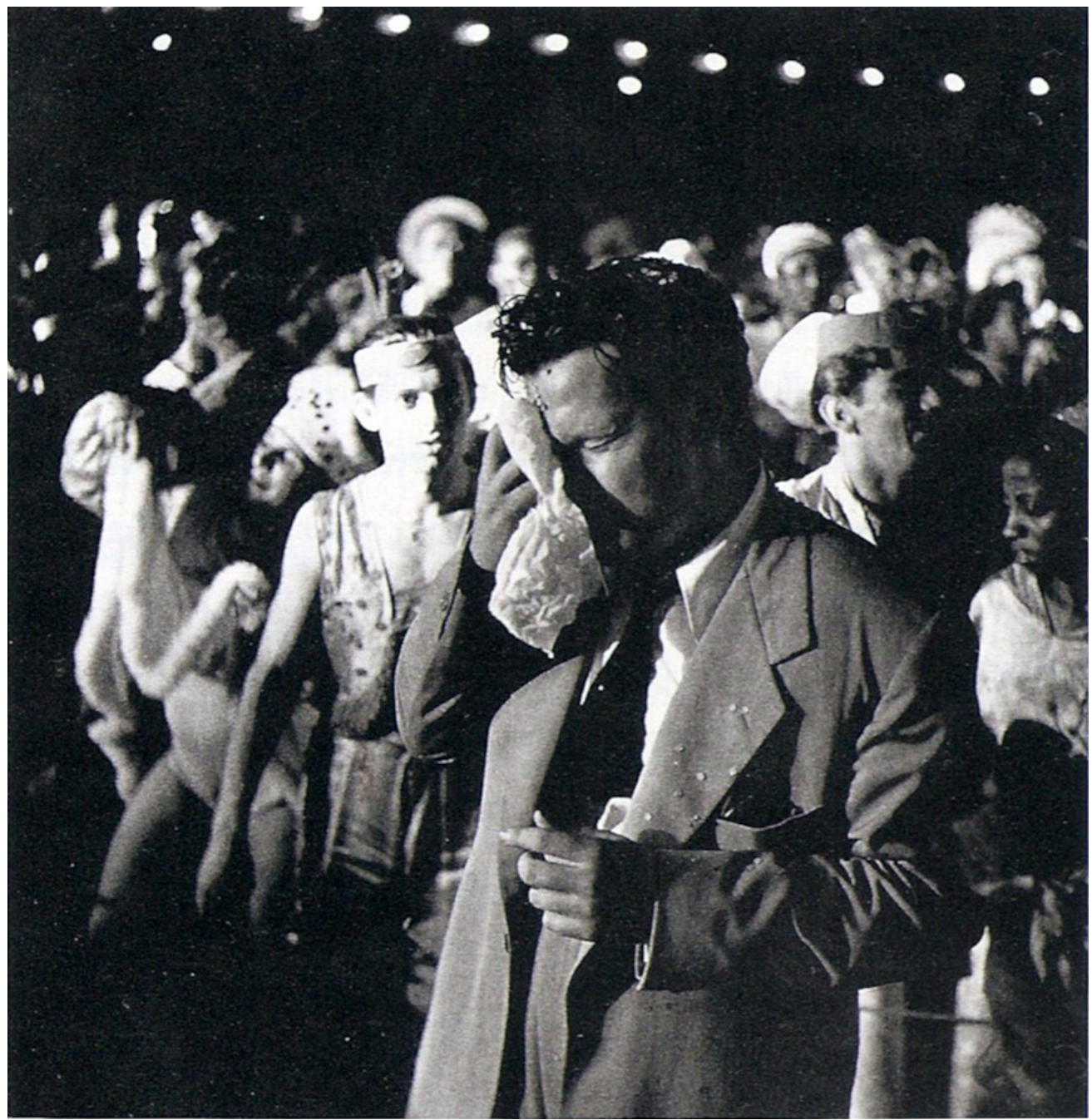

Figura 25 - Orson Welles no carnaval carioca, 1942, Genevieve Naylor, coleção Peter Reznikof@.

As imagens da fotógrafa da Boa Vizinhança sintonizaram com um novo ritmo dado às interpretações da cultura popular brasileira dos anos 1940. Nesse momento, a ideia de povo tradicionalmente folclorizado pelas leituras românticas oitocentistas incorporou elementos da presença negra na cultura urbana e de mercado, principalmente o fonográfico, delimitando um novo lugar social de fala, autorizado para a produção de representações sociais sobre o povo brasileiro, com certeza, mais moreno.

Nessa perspectiva, as negociações entre os "mundos" negro e branco definem as táticas e estratégias culturais que orientaram o cotidiano da cidade. As duas músicas escolhidas para compor essa relação intertextual amplificam a tensão entre a cultura erudita, com a qual as elites queriam defender como marca da identidade brasileira no exterior, e cultura popular de massa ${ }^{34}$. A leitura videográfica desse material, desenvolvida com base no princípio de intertextualidade ${ }^{35}$, permite 
a configuração de uma nova interpretação histórica sobre a cultura política do período analisado, em que se valorizam as escolhas estéticas e formais da fotógrafa em relação à letra, melodia e ritmo das músicas cantadas no carnaval de 194036.

Ambas as músicas foram cantadas por Carmen Miranda e possuem uma raiz eminentemente popular, pois seus autores, Synval Silva e Nelson Petersen, foram ligados ao círculo do sambista carioca Assis Valente ${ }^{37}$. $\bigcirc$ mundo do samba de então era composto por compositores tanto provenientes das camadas populares de diferentes estados do Brasil - que vinham para o Rio de Janeiro, então Capital Federal, tentar a sorte, a fortuna e o estrelado, no emergente mundo do rádio como por jovens das camadas médias que se encantavam pela boemia carioca ${ }^{38}$. Ambos os compositores foram apresentados por Assis Valente a Carmen Miranda, que antes de fazer carreira internacional já era reconhecida nos meios artísticos nacionais como a madrinha do samba de raiz popular.

As letras dos dois sambas têm como argumento central a valorização do ritmo do morro e da população negra, como elementos de identificação da cultura brasileira. Ao mesmo tempo em que deixam evidentes as tensões sociais que existem na incorporação de elementos da cultura popular à cultura brasileira hegemônica:

\section{Gente Bamba}

(Synval Silva, 1937)

Salve, Salve

As nossas escolas de samba

Que no sapateado, meu povo

É um desacato

Um samba é feito

Com gente bamba

Tem tamborim tem cuíca

Pandeiro e mulato

Com um pandeiro, uma cuíca

Um tamborim

É que se forma um samba

E o mulato sempre foi

Indispensável num

Conjunto de cabrocha bamba

No samba se tem alegria

Podes crer

No morro se tem alegria de viver

(Salve, Salve)

Lá no morro da Formiga

Ou do Borel se vê a Casa Branca

Se ouve o gemido da cuíca

Dando todos a carta branca

No samba se tem alegria, podes crer

No morro se tem alegria de viver

\section{Quem Condena a Batucada}

(Nelson Petersen, 1938)

Quem condena a batucada

Dessa gente brozeada

Não é brasileiro

E nada mais bonito é

Que um corpo de mulher

A sambar no terreiro

Já falaram que o samba do morro

Não tem coração

Só se fala em navalha e cabrocha

E até Parati

É bem fácil acabar com essas coisas

Do samba-canção

É, mas eu só quero ver é acabar

Com os malandros

Que têm por aí

Já disseram que o samba nasceu

Num palácio real

E depois se criou e cresceu

Em salão multicolor

Mas não sabem que o samba nasceu

Num cruel barracão

E que foi educado sambando no chão

Com a gente de cor.
Heitor dos Prazeres, que muito o incentivou. A 13 de maio de 1941, no apogeu de sua carreira de compositor, o Rio de Janeiro foi sacudido com a notícia de que ele se tinha atirado do Corcovado e, milagrosamente, preso a um galho de árvore, do qual fora libertado por uma equipe do Corpo de Bombeiros. Mas, embora salvo, moralmente prosseguiu em sua queda do abismo. Nunca mais foi o mesmo", cf. Dicionário Cravo Albin da Música.

38. A trajetória de ambos os compositores evidencia as marcas da procedência social dos sambistas: "Synval Machado da Silva nasceu em Juiz de Fora, MG, em 14 de março de 1911, filho de um clarinetista. Em 1930, mudou-se para o Rio de Janeiro, indo morar no Morro da Formiga. Tocou violão na Rádio Mayrink Veiga, onde conheceu Assis Valente que, em 1934, o apresentou àquela que iria mudar para sempre a sua vida: Carmen Miranda. Synval tornou-se o compositor favorito de Carmen - a primeira canção gravada por ela foi Ao Voltar do Samba, ainda em 1934 , fazendo um grande sucesso. Carmen prometeu dois contos de réis (um dinheirão para a época) se Synval lhe fizesse um samba que alcançasse metade do prestígio conseguido por $A o$ Voltar... o resultado foi Coração, sucesso em 1935. Carmen então ofereceu três contos de réis por nova composição, resultando dessa vez em Adeus Batucada. Cf. <http://www. sa mba-choro.com.br/ artistas/synvalsilva>, acesso em 2/03/2011. Nelson Petersen, filho de um médico e dono de uma escola tradicional no Rio de Janeiro, tinha somente 19 anos quando foi apresentado a Carmem por Assis Valente. Como seu pai não concordava com a vida da boemia, obrigou-o a largar 
as rodas de samba e a se tornar professor de inglês em sua escola; ver Ruy Castro (2005, p.162).

39. O instrumento de pesquisa intitulado $A$ presença negra nas revistas ilustradas nas décadas de 1930-1950, é um dos resultados do projeto de pesquis a Imagens contemporâneas: a prática fotográfica e os sentidos da bistória nas revistas ilustradas, 1930-1960, financiado pelo $\mathrm{CNPq}$, por meio bolsa de produtividade (2008-2011).

40. O marco dos anos 1960 é delimitado pelo processo de remoção das favelas de morros da Zona Sul da cidade, entre os quais Pasmado, Cantagalo e Humaitá, incluindo as favelas da Praia das Dragas e da Praia do Pinto, no entorno da Lagoa Rodrigo de Freitas. A população que habitava essas regiões deu origem a uma nova zona suburbana, dentre essas a in ternacionalmente conhecida Cidade de Deus. Sobre a erradicação das favelas cariocas nos anos 1960, cf. Amoroso, 2011.

41. Ver Maurício de Abreu (2006).

42. Ver Ruy Castro (2005).
A presença de representações sobre a população negra nos veículos associados à cultura popular de massa, notadamente na indústria fonográfica, com os sambas, e na imprensa ilustrada ${ }^{39}$, acaba por ratificar as diferenciações delimitadas por uma espécie geografia histórica e social que caracterizou o espaço social da cidade do Rio de Janeiro, até meados dos anos $1960^{40}$. As favelas dos morros da área central e da Zona Norte tijucana (como Borel e Formiga) eram tradicionalmente habitadas pelas camadas pobres da população, que necessitavam morar perto do trabalho; quando a cidade passou a contar com uma malha ferroviária eletrificada em seus trens suburbanos, em 1937, a ocupação dos morros ganhou também os bairros mais distantes, como Madureira ${ }^{41}$.

movimento de suburbanização da população trabalhadora vai construir um conjunto de representações culturais diversas daquela que fundaram 0 imaginário popular das favelas cariocas, como as letras dos sambas acima expressam. Portanto, essas letras de músicas revelam um conjunto de representações pelas quais a população afro-brasileira da cidade era, por um lado, identificada com alegria, descontração e sensualidade, como ingredientes de uma brasilidade renovada pelo processo de incorporação do popular ao nacional; por outro, marcavam a divisão de classes e sua condição de subalternidade.

Vale ressaltar que Carmen Miranda, a intérprete dos sambas, era branca, nascida em Portugal, mas "batizada" como brasileira e próxima da fina flor do samba de raiz carioca de então. Filha de imigrantes portugueses pobres, moradora da Lapa, região contígua à área central da cidade, onde a família mantinha uma pensão diurna que oferecia refeições, desde jovem Carmen trabalhou e conviveu com diferentes grupos sociais que circulavam pela região onde morava. Em 1929, aos 21 anos, estoura no mundo do samba com a canção de Joubert de Carvalho denominada Taí, que inicia sua consagração como cantora ${ }^{42}$.

Da Lapa para o estrelato em Hollywood, foram vários sucessos no rádio e no teatro, que imortalizaram Carmen Miranda como a interprete, por excelência, da alma multicultural do Brasil de então. Ícone do processo de internacionalização cultural pelo qual o Brasil passaria durante e depois da Segunda Guerra, Carmen Miranda se fantasiava de baiana estilizada e se tornou o símbolo do Brasil que deu certo no estrangeiro, cantando samba, a música que veio dos morros. Embora branca (e talvez justamente por isso), Carmen foi, portanto, a intérprete aceita para internacionalizar aquele ritmo afro-brasileiro, o samba, que se tornaria um ícone do país "bom vizinho". Esse Brasil era diferente e mestiço, mas dado a ver e embranquecido o suficiente para ser afirmado no exterior por uma política de Estado que, mesmo aceitando o país multi étnico e cultural, ainda priorizava para um ícone visual, a cantora de origem branca, 100\% europeia como Carmen.

Os morros da cidade do Rio de Janeiro, o carnaval, o samba e sua a ginga, o movimento do corpo e a população negra da cidade compõem o repertório visual das fotografias de Naylor, mas também se encontram nas letras e ritmos das músicas cantadas por Carmem Miranda. Ambas unidas no compasso da política internacional: o de apresentar a imagem do Brasil como um bom vizinho 
dos Estados Unidos. Por outro lado, a trama composta pelos sambas e fotografias, potencializadas pelo recurso audiovisual, evidenciam o embate entre alteridades e identidades afro-brasileiras, cruzando os olhares e expressando a experiência histórica. $\bigcirc$ que nos permite visualizar os significados atribuídos e as tensões levantadas pela políitica da Boa Vizinhança, ao ressignificar a frase fundadora da doutrina Monroe: "A América para os americanos", ainda que bastante distintos.

\section{Conclusão}

As fotografias produzidas por Genevieve Naylor durante a sua estadia no Brasil foram filtradas pelas mediações culturais que concorreram para a elaboração do seu olhar. Assim, a formação e experiência profissional definiram prática fotográfica, seja devido a sua participação nos projetos comunitários do Harlem nos EUA, seja pela forma como compartilhava os valores humanísticos com a intelectualidade brasileira, que discutia a presença da população negra na identidade nacional no Brasil, ou ainda, por sua interação cotidiana com o país que visitara oficialmente. A experiência fotográfica de Naylor apoiou-se na economia visual e na cultura política orientadas pela noção de igualdade dos povos, que configurou o Brasil aos olhos dos norte-americanos.

O Brasil, nas lentes de Naylor, não era o bom vizinho que a política de governo dos EUA pregava, ou que as autoridades brasileiras desejam exportar, mas um país vibrante, multicultural e pleno de contradições. Nesse sentido, a fotografia de Naylor se inscreve no âmbito de uma das modalidades de fotografia pública do século XX, por atribuir significados políticos à imagem fotográfica ao lança-la no espaço público dos museus, arquivos e outras arenas culturais. 


\section{REFERÊNCIAS}

AMOROSO, Mauro. Nunca é tarde para ser feliz? A imagem das favelas pelas lentes do Correio da Manhã. Curitiba: CRV, 2011.

ABREU, Mauricio. Evolução urbana do Rio de Janeiro, $4^{\mathrm{a}}$ ed.. Rio de Janeiro: Editora Instituto Pereira Passos, 2006.

BURGIN, Victor. Looking at Photographs. In: (ed.) Thinking Photography. Londres: The MacMillan Press, 1982. p.142-153.

CASTRO, Ruy. Carmen: a vida de Carmen Miranda, a brasileira mais famosa do século XX. Rio de Janeiro: Companhia das Letras, 2005.

CURTIS, James. Mind's eye, mind's truth: FSA photography reconsidered. Philadelphia: Temple University Press, 1989.

DANIEL, Pete et al. Official Images: New Deal Photography. Washington (DC): Smithsoniam Institution Press, 1987.

DICIONÁRIO Cravo Albin da Música, <http://www.dicionariompb.com.br/assis-valente/ biografia>, acesso em 02/03/2011.

DONOGHUE, Denis et.al.. A América em teoria. Rio de Janeiro: Forense Universitária, 1993.

ERMAKOFF, George. Genevieve Naylor: uma fotógrafa norte-americana no Brasil, 1940-1942. Rio de Janeiro: G. Ermakoff Casa Editorial, 2013.

GUIMARÃES, Antonio Sergio Alfredo. Racismo e antirracismo no Brasil, 3a ed. São Paulo: Editora 34, 2009.

HURLEY, Forest Jack. Portrait of a Decade: Roy Styker and the Development of Documentary Photography in the Thirties. Nova York: Da Capo Press, 1977.

KRACAUER, Siegfried. Photography. In: TRACHETENBERG, Alan (ed.). Classic Essays on Photography. New Haven: Leete's Island Books, 1980. p. 245-268.

LEVINE, Robert. Brazilian Photographs of Genevieve Naylor, 1940-1942. Durham, Londres: Duke University Press, 1998.

MACHADO, Aníbal. Nada de Cachoeiras. Diário de Notícias, Rio de Janeiro, 28/12/1941.

MATTOS, Hebe. Das cores do silêncio, $3^{\text {a }}$ ed. Campinas: Ed. Unicamp, 2013.

MAUAD, Ana Maria. As três Américas de Carmem Miranda: cultura política e cinema no contexto da política da boa-vizinhança. Transit Circle, Rio de Janeiro, v.1, p.52-77, 2002.

Genevieve Naylor, fotógrafa: impressões de viagem (Brasil, 1941-1942). Revista Brasileira de História, São Paulo, v. 25, n.49. p. 43-76, 2005. 
MAUAD, Ana Maria. Poses e flagrantes: ensaios sobre história e fotografias. Niterói: EDUFF, 2008.

America is Here: The Good-Neighbor Policy and the Cultural Influence of North America on Brazilian Advertising Images (1940-1950). Transit Circle, Rio de Janeiro, v.2, p.12 - 28, 2009.

Na sintonia bananorítmica: cinema e cultura política durante a Era da Boa Vizinhança. In: BEIRED, José Luis Bendicho et al. (org.). Intercâmbios políticos e mediações culturais nas Américas. Assis: UNESP Publicações, 2010. p. 333-360.

MAUAD, Ana Maria, DUMAS, Fernando, SERRANO, Ana Paula da Rocha. Video-História e História Oral: Experiências e reflexões. In: VISCARDI, Cláudia M.R., DELGADO, Lucília de A. Neves (org.). História oral: teoria, educação e sociedade. Juiz de Fora: Ed.UFJF/ABHO, 2006. p.33-57.

MONTEIRO, Erica Gomes Daniel. Quando a guerra é um negócio: F. D. Roosevelt, iniciativa privada e relações interamericanas durante a II Guerra Mundial. Rio de Janeiro: Ed. Prismas, 2014.

MORAES, Vinícius de. A Última Catedral. A Manhã, Rio de Janeiro, 19/10/1941.

Orson Welles em filmagem. A Manhã, Rio de Janeiro, 30/04/1942.

MOTA, Carlos Guilherme. Cultura e política da boa vizinhança: dois artistas norte-americanos no Brasil. In: Coggiola, Oswaldo (org.). Segunda Guerra Mundial: um balanço histórico. São Paulo: Xamã/FFLCH/USP, 1995. p. 489-501.

MOURA, Gerson. Tio Sam chega ao Brasil: a penetração cultural americana, $5^{\text {a }}$ ed.. São Paulo: Brasiliense, 1988.

ORTIZ, Renato. A moderna tradição brasileira. São Paulo: Brasiliense, 1989. Cultura brasileira e identidade nacional, $5^{\mathrm{a}}$ ed.. São Paulo: Brasiliense, 1994.

PIKE, Frederick B. The United States and Latin America: Myths and Stereotypes of Civilization and Nature. Austin: University of Texas Press, 1992.

RISÉRIO, Antonio. A utopia brasileira e os movimentos negros, $2^{\mathrm{a}}$ ed.. São Paulo: Editora 34, 2012.

ROSLER, Martha. Imágenes públicas: La función política de la imagen. Barcelona: Editorial Gustavo Gili, 2007.

SCHWARCZ, Lilia Moritz. O espetáculo das raças: cientistas, instituições e questão racial no Brasil, 1870-1930. São Paulo: Ed. Claroenigma, 2012.

SIRINELLI, Jean-François. A geração. In: FERREIRA, Marieta, AMADO, Janaína (org.). Usos $e$ abusos da bistória oral. Rio de Janeiro: Editora FGV, 1996. p. 131-138.

TOTA, Antônio Pedro. O imperialismo sedutor. São Paulo: Companhia das Letras, 2000.

Artigo apresentado em 21/08/2012. Aprovado em 05/04/2014. 